ELIGHTTO IQUIDITY ELOWS

IN THE EURO AREA SOVEREIGN

DEBT CRISIS

Juan Angel Garcia and Ricardo Gimeno

Documentos de Trabajo

N. 1429

banco gespaña

Eurosistema 
FLIGHT-TO-LIQUIDITY FLOWS IN THE EURO AREA SOVEREIGN DEBT CRISIS 


\title{
FLIGHT-TO-LIQUIDITY FLOWS IN THE EURO AREA SOVEREIGN DEBT CRISIS
}

\author{
Juan Ángel García (*) \\ EUROPEAN CENTRAL BANK \\ Ricardo Gimeno ${ }^{(* *)}$ \\ BANCO DE ESPAÑA
}

\begin{abstract}
(*) We are grateful to Hans Dewachter, Simone Manganelli, Daisuke Miyakawa, Juan Nave, Paolo Pasquariello, Fulvio Pegoraro, Gabriel Pérez-Quirós, Marcello Pericolli, Marti Subrahmanyam and numerous colleagues and seminar participants at the Banco de España, the 2013 Finance Forum, the 1st International Conference on Sovereign Bond Markets at Waseda University in Tokio, the Third Joint Bank of Canada Banco de España Workshop on "International Financial markets" and an anonymous referee for comments and suggestions on earlier drafts. All remaining errors are our responsibility. We are also grateful to Francisco Alonso and Eduardo Maqui for their research assistance. The views expressed are those of the authors and do not necessarily reflects those of the ECB or the Banco de España.

$\left.{ }^{* *}\right)$ Capital Markets Division, European Central Bank, Kaiserstrasse 29, D-60311 Frankfurt am Main, Germany. Contact: juan_angel.garcia@ecb.int

${ }_{\left({ }^{\star \star}\right)}$ Corresponding author, Servicio de Estudios, Banco de España, Alcalá 48, 28014 Madrid, Spain. Contact: ricardo.gimeno@bde.es
\end{abstract}


The Working Paper Series seeks to disseminate original research in economics and finance. All papers have been anonymously refereed. By publishing these papers, the Banco de España aims to contribute to economic analysis and, in particular, to knowledge of the Spanish economy and its international environment.

The opinions and analyses in the Working Paper Series are the responsibility of the authors and, therefore, do not necessarily coincide with those of the Banco de España or the Eurosystem.

The Banco de España disseminates its main reports and most of its publications via the Internet at the following website: http://www.bde.es.

Reproduction for educational and non-commercial purposes is permitted provided that the source is acknowledged.

C BANCO DE ESPAÑA, Madrid, 2014

ISSN: 1579-8666 (on line) 


\section{Abstract}

In periods of market stress, portfolio reallocations in bond markets reflect both safety and liquidity concerns. Using sovereign and national agency bonds, we construct indicators of liquidity premia in major euro area bond markets; we document the weakening of the correlation between core and periphery market liquidity during the euro area sovereign bond crisis; and we identify several episodes of significant flight-to-liquidity (FTL) flows above and beyond flight-to-safety (FTS) spells in the period 2009-13. We show that FTL flows led to significant inverse moves in sovereign bond yields in euro area core and periphery markets. Moreover, FTL flows triggered declines in core and periphery stock markets and are associated with lower macroeconomic confidence in the euro area as a whole, which underscores the importance of FTL episodes for investors and policymakers alike.

Keywords: liquidity premia, flight to liquidity, flight to safety, sovereign debt crisis.

JEL Classification: G01, G12, H63. 


\section{Resumen}

En períodos de tensión en los mercados financieros, recomposiciones en las carteras de renta fija pueden generarse por la preocupación no solo por el riesgo de crédito, sino también por el riesgo de liquidez. Usando información de bonos emitidos por Gobiernos y agencias públicas, construimos indicadores de las primas de liquidez en los principales mercados de bonos de la zona del euro, mostrando el debilitamiento de la correlación en la liquidez de los mercados de los países del núcleo y de la periferia durante la crisis de la deuda soberana europea, e identificando varios episodios de significativos flujos de huida a la liquidez (flight-to-liquidity, FTL), además de los flujos de huida a la seguridad (flight-tosafety, FTS), durante el período 2009-2013. El análisis demuestra que los flujos FTL provocaron movimientos significativos en direcciones opuestas en los rendimientos de los bonos soberanos entre los mercados de los países centrales y de la periferia de la zona del euro. Por otra parte, los flujos de FTL produjeron descensos en todos los mercados de valores de la zona del euro y están asociados, a escala macroeconómica, con una menor confianza económica en el conjunto de la zona del euro, lo que pone de relieve la importancia de los episodios FTL tanto para los inversores como para la toma de decisiones de política económica.

Palabras clave: prima de liquidez, huida a la liquidez, huida a la seguridad, crisis de deuda soberana.

Códigos JEL: G01, G12, H63. 
In periods of market stress, extreme and inverse market movements in the bond and equity markets are often referred to as "flights to safety" or "flights to quality". Such episodes were relatively frequent during the sovereign debt crisis in the euro area. The decrease in value of periphery sovereign debt was undoubtedly related to changes in perceived default probabilities and thereby in the increase in the required premium for bearing that credit risk. Under those circumstances, some market participants were willing to decrease their portfolio exposure to securities bearing the perceived higher credit risk triggering sudden swings in bond prices. In an influential paper, Baele et al. (2013) document flight-to-safety episodes in more than 20 bond markets and show that such episodes are important to understand developments in major bond markets.

Flights to safety episodes may be however related not only to flights to quality but also about flights to liquidity. In periods of market turbulence, the liquidity of the bonds, i.e. the capacity to undo positions at reasonable costs, is also an important concern for bond market investors. Abrupt changes in bond prices may therefore be the result of flight to liquidity episodes when market participants suddenly prefer to hold highly liquid securities rather than less liquid ones, thereby requesting a higher premium for holding the less liquid bonds, in addition to or even regardless their credit risk.

Developments in euro area bond markets in the period 2009-13 are an important example of the relevance of flight to safety and flight to liquidity episodes. As an illustration, Figures 1 depict a simple decomposition of sovereign bond yields in three major euro area countries (Germany, Spain and France) using OIS rates as proxy for risk-free interest rates and CDS premia as proxy for credit risk compensation.

Figure 1: Five-year sovereign bond yields compared to the sum of OIS rates and CDS premia
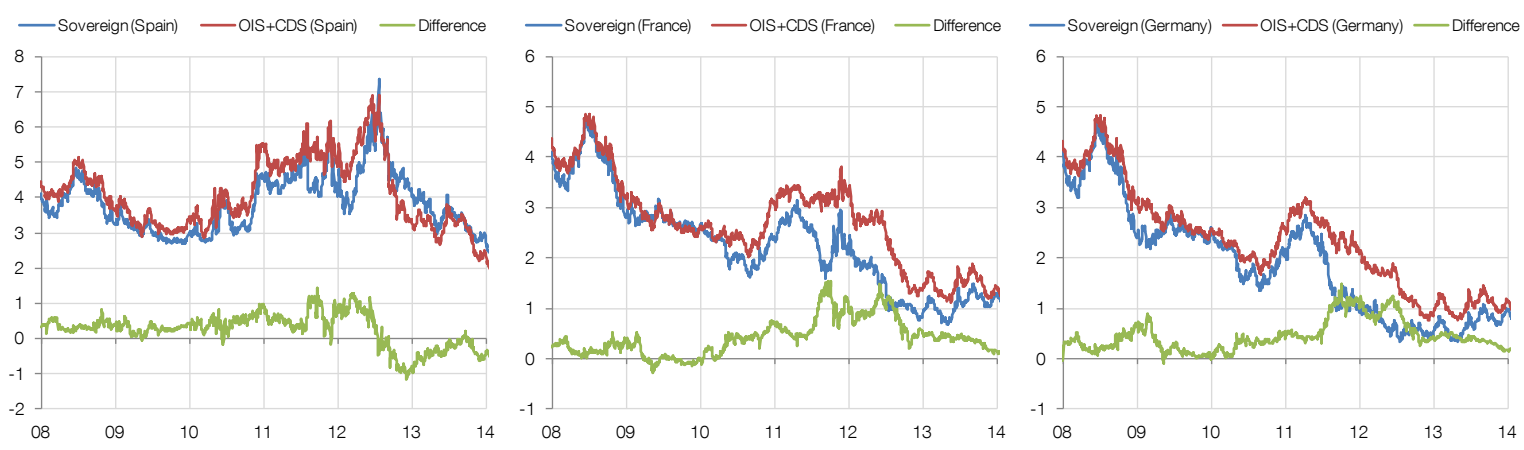

Note: 5-year spot yield of the sovereign (blue line) and the sum of the 5-year Overnight Interest Rate Swap (OIS) rate and the 5year CDS (percentage points, red line), as well as the difference between both series (green line). Left chart represent data for Spain, centre chart for France, and right one for Germany.

While the combined effect of monetary policy expectations and credit risk compensation help mimic quite well developments in observed sovereign yields in those markets, it is also evident that both effects are insufficient to fully explain the observed bond yields, leaving more than 100 basis points unaccounted for at times and stressing the role of flight to liquidity flows. 
Against this background, the goal of this paper is to investigate the dynamics of liquidity premium in euro area bond markets during the financial and sovereign debt crisis. In particular, we show that flight to liquidity flows were an important dimension of the turbulences experienced in bond markets during the global financial crisis and in particular in the euro area bond markets, beyond and above flight to safety episodes.

A major challenge to analyse the impact of liquidity considerations in sovereign bond yields is that the liquidity premium is unobservable, so its identification relies on the use of some proxies that imperfectly capture some aspects of liquidity (e.g.: traded volumes, bid-ask spreads). Unfortunately, such measures are not always available or their reliability differs across bond markets, which makes it difficult drawing sound conclusions for multi-country analysis.

In this paper, we take a more direct approach by looking at more direct proxies of liquidity premium. To measure changes in liquidity premium in individual bond markets, we calculate yield spreads between sovereign bonds and equivalent bonds issued by government sponsored agencies of Germany (Kreditanstalt fur Wiederaufbau, KfM), France (Caisse d'Amortissement de la Dette Sociale, CADES) and Spain (Instituto de Crédito Oficial, ICO). Specifically, we estimate both sovereign and agency zero-coupon term structures of bond yields and calculate the spreads at the five year maturity for three of the largest bond markets in the euro area: Germany, France and Spain. The rationale is that, being fully guaranteed by the governments, the bonds issued by such agencies have the same credit risk as the bonds issued by the respective treasuries, and yield spreads, therefore, provide evidence of the liquidity premium in each bond market. Longstaff (2004) indeed showed that agency spreads capture a substantial part of the flight to safety episodes in the US bond market using yield spreads between US Treasuries and bonds issued by the Resolution Funding Corporation (Refcorp).

We analyse the time-varying co-movement of liquidity premium across those three euro area bond markets in recent years and document significant swings in liquidity premium in euro area bond markets between 2008 and 2013. Following the collapse of Lehman Brothers, liquidity premium rose across all bond markets as a result of strong flight-to safety flows. Later on, however, the unfolding of the sovereign debt crisis in some euro area countries led to a gradual increase in the market discrimination across sovereign issuers with strong episodes of flight-to-liquidity since late 2009 between Spanish and AAA-rated sovereign bonds (French and German ones) and from 2011 even between AAA-rated bonds.

To isolate pure flight to liquidity effects from those associated with more general flight to safety episodes in sovereign bond markets, we estimate a dynamic two-factor model using the liquidity spreads for Germany, France and Spain. Since one of the factors is strongly related to stock market volatility and therefore helps account for the influence to flight to safety flows, the second factor allows us to identify liquidity effects more directly linked to flight to liquidity flows.

We show that flight to liquidity was an important element of the financial turbulences during the euro area debt crisis. The reaction in euro area sovereign bond markets was clearly asymmetric: while sovereign yields from "stressed" countries (Spain, Italy, Greece, Portugal and Ireland) increased as a result of flight to liquidity flows, yields of "core" countries (Germany, France, Austria, Belgium, Finland and The Netherlands) decreased significantly. Moreover the yield impact of flight to liquidity flows was sizeable: our estimates suggest a variation in Spanish five-year sovereign bond yield of around 80 basis points during the crisis solely as a result of flight to liquidity pressure. 
The importance of flight to liquidity flows is further underscored by the fact that their effects extended well beyond sovereign bond markets. We show that euro area stock markets were negatively affected by flight to liquidity flows. In stark contrast to bond markets, stock markets in both core and stressed countries exhibited significant declines in returns during flight to liquidity episodes, even after controlling for a potential simultaneous flight to safety effects. Furthermore, we also find evidence of deterioration in economic confidence associated to flight to liquidity episodes, which suggest that such episodes were perceived not only by financial market investors but by economic agents in general as an important element of the euro area crisis that should be taken into account.

Our results provide strong evidence in support of market liquidity playing an important role to understand movements in sovereign yield spreads in the euro area in recent years. Beber et al. (2009) already showed that even before the financial and debt crisis in times of market stress, investors in the Euro-area sovereign bond market demand liquidity rather than credit quality in their portfolios. Our evidence based on the available agency spreads for three different countries suggests that such practices are likely to have intensified in recent years as a result of the financial and sovereign debt crisis. Schwarz (2010) also uses $\mathrm{KfW}$ spreads as proxies for liquidity in euro area bond markets. There is also an ample theoretical literature arguing in favour of the presence of significant effects of liquidity in asset pricing (e.g.: Vayanos, 2004; Caballero and Krishnamurthy, 2008; Brunnermeier and Pedersen, 2009, among others).

The rest of the paper is organised as follows. Section 2 introduces the computation of the liquidity spreads for Germany France and Spain. In Section 3 we describe our identification strategy for flight to liquidity flows and their characteristics during the euro area debt crisis. We then investigate the quantitative impact of flight to liquidity flows in all euro area sovereign bond and stock markets, as well as on economic confidence in Section 4. Finally, Section 5 concludes. 


\section{Measuring liquidity premia in euro area bond markets}

From a practical point of view, the yield of a given bond $\left(i_{t}(s)\right)$ can be decomposed into riskfree interest rates $\left(r_{t}\right)$, credit risk compensation $\left(c_{t}(s)\right)$ and liquidity risk compensation $\left(l_{t}(s)\right)$ :

$i_{t}(s)=r_{t}+c_{t}(s)+l_{t}(s)$

For this reason, when considering a sovereign spread (the difference between the yields of two sovereign bonds issued, for instance, by Spain and Germany), their spread will include the difference in the credit risk premia as well as differences in the liquidity premia.

$\left[i_{t}\left(s_{1}\right)-i_{t}\left(s_{2}\right)\right]=\left[c_{t}\left(s_{1}\right)-c_{t}\left(s_{2}\right)\right]+\left[l_{t}\left(s_{1}\right)-l_{t}\left(s_{2}\right)\right]$

By contrast, an agency bond spread (the yield spread between a bond issued by an agency owned by the government and the corresponding sovereign bond) will allow cancelling out the credit risk and therefore isolating the liquidity premia (Longstaff, 2004): ${ }^{1}$

$X_{t}^{s_{1}}=\left[i_{t}\left(s_{1}\right)-i_{t}\left(a_{1}\right)\right]=\left[l_{t}\left(s_{1}\right)-l_{t}\left(a_{1}\right)\right]$

Clean measures of liquidity premium in each bond market can therefore be obtained by computing the yield spread between standard sovereign and agency bonds. We would however need bonds with exactly the same maturity and structure of payments (frequency and size of coupons, as well as principal) or the spreads would be affected by differences in term premia and changes in the benchmarks.

We therefore compute yield spreads on daily zero-coupon term structures estimated using a Nelson Siegel parametric specification (Nelson and Siegel, 1987) for Spanish, French and German government bonds, as well as for their respective agency bonds (ICO, CADES and KfW), between January 2008 and December 2013. Our choice of the Nelson Siegel specification is motivated by the limited number of agency bonds in some markets. Despite its simplicity, the Nelson Siegel specification is widely used among central banks (see, BIS 2005). To ensure the stability of the estimated parameters we employed the genetic algorithm introduced in Gimeno and Nave (2009). ${ }^{2}$

Within the estimated term structures, in the light of the available agency market structures, we focus on five year spreads as benchmark maturity (see Figure 2). Moving beyond the five-year maturity reduces the number of available bonds and lowers the reliability of the zero-coupon term structures (see Figure A1 in the Appendix). ${ }^{3}$ We will nonetheless show that our main findings hold for two and ten-year maturities, too.

1. The analyses in Schwarz (2010) and Ejsing et al. (2012) are also based on the assumption that KfW and CADES bond yields have the same level of credit risk as their government counterparts.

2. The procedure involves a heuristic search of the optimum that mimics the process of natural evolution and explores the whole parameter universe, and including random perturbations around solutions to avoid local minima.

3. The Appendix also includes a list and the main characteristics of the bonds used in our estimation. 
Figure 2: 5-year zero-coupon bond yields
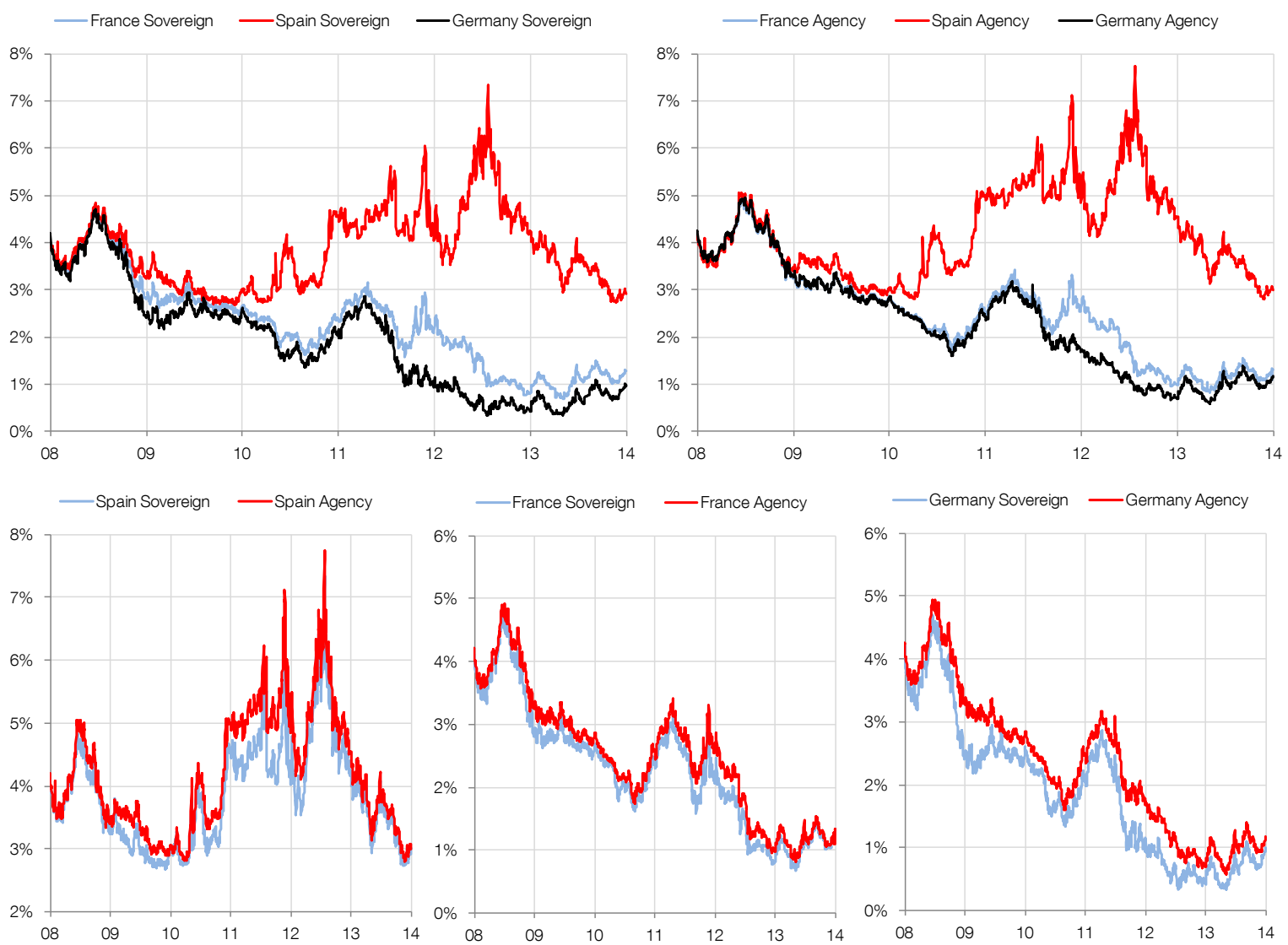

Note: Yields are computed from a Nelson-Siegel yield curve estimated daily with Gimeno and Nave (2009) algorithm. The left hand side chart represents the 5-year rate for the Spanish (red), German (black), and French (blue) Sovereign (Government) bonds. The right hand side chart represents the 5-year rate for the ICO (Spanish, red), KfW (German, black), and CADES (French, blue) Agency bonds. Below are the same series but represented by country (Spain, left; France, centre; and Germany, right), with agency rates in red and sovereign rates in blue.

Figure 2 shows that in some periods (e.g. late 2008-early 2009) there is a higher variation in government bonds than in agency bonds. Once we recover the corresponding agency spreads (agency rate minus the sovereign bond yield, see Figure 3), it is apparent that liquidity premia dynamics played an important role in the widening of the intra-euro area sovereign yield spreads.

Table 1 provides descriptives statistics for both our sovereign and agency yields as well as country- specific agency spreads, both for levels and first differencies. As yields and agency spreads are highly persistent, we below specify our models in terms of first differences to work with stationary time series. We can also observe that, as a consequence of the crisis, Spanish yields, both sovereign and agency, have extreme values, as the kurtosis coefficients highlights (this also produce some correlation with the first lag). 
Figure 3: Agency Spreads for five-year maturity bond yields

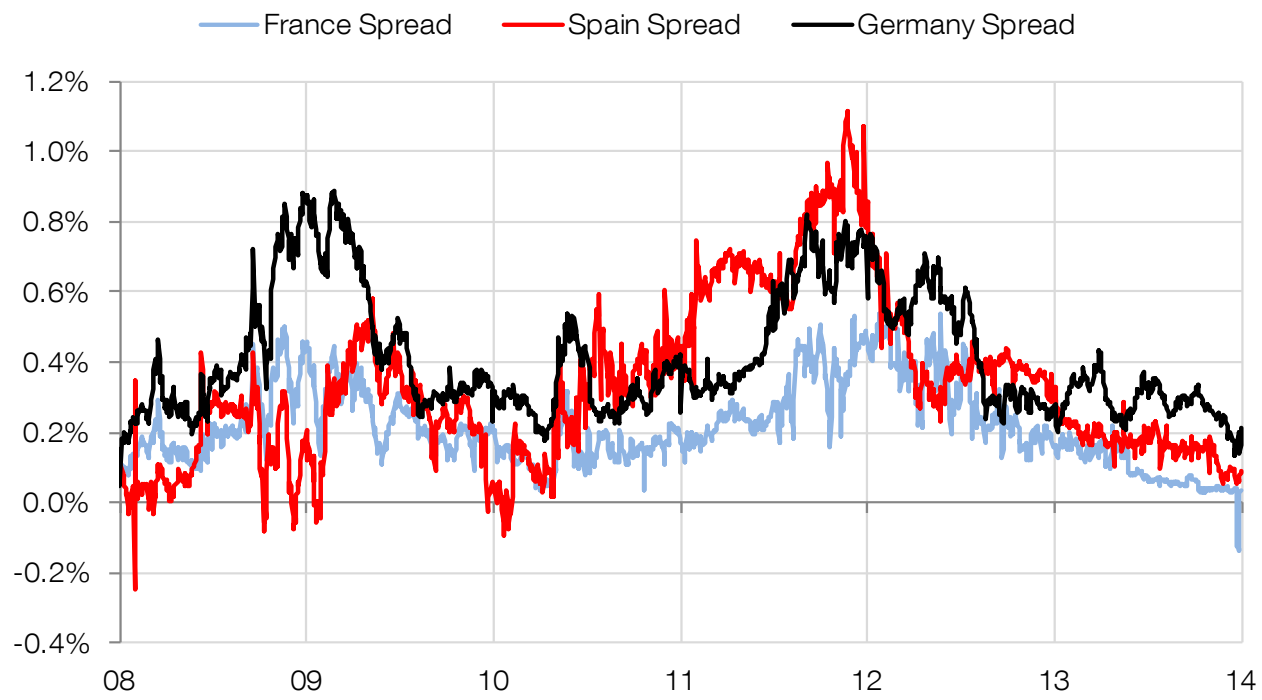

Note: Computed as the difference of the 5-year spot yield of the agency minus the 5-year spot yield of the corresponding sovereign (percentage points). For France (blue line), the agency is CADES; for Spain (red line), the agency is ICO; and for Germany (black line), the agency is KfW.

Table 1: Descriptive statistics for the involved variables

\begin{tabular}{|c|c|c|c|c|c|c|c|}
\hline & ean & STDev. & Skewness & Kurtosis & Corr(1) & Corr(2) & Corr(3) \\
\hline \multicolumn{8}{|l|}{ Level } \\
\hline ICO (Spain) & 4.17 & 0.96 & 0.63 & 2.79 & .994 & .986 & .978 \\
\hline KfW (Germany) & 2.29 & 1.12 & 0.35 & 2.19 & .998 & .996 & .994 \\
\hline CADES (France) & 2.48 & 0.99 & 0.24 & 2.39 & .997 & .995 & .992 \\
\hline ES sovereign & 3.84 & 0.83 & 0.73 & 3.37 & .992 & .981 & .971 \\
\hline DE sovereign & 1.87 & 1.11 & 0.48 & 2.33 & .997 & .994 & .992 \\
\hline FR sovereign & 2.27 & 0.96 & 0.38 & 2.53 & .997 & .994 & .991 \\
\hline ES agency spread & 0.33 & 0.23 & 0.86 & 3.41 & .982 & .974 & .966 \\
\hline DE agency spread & 0.41 & 0.18 & 0.93 & 2.71 & .990 & .981 & .973 \\
\hline \multirow[t]{2}{*}{ FR agency spread } & 0.22 & 0.12 & 0.61 & 2.82 & .972 & .948 & .926 \\
\hline & Mean & STDev. & Skewness & Kurtosis & Corr(1) & Corr(2) & Corr(3) \\
\hline \multicolumn{8}{|l|}{ First Difference } \\
\hline ICO (Spain) & -.001 & .097 & -1.34 & 17.46 & .212 & .015 & -.079 \\
\hline KfW (Germany) & -.002 & .044 & 0.20 & 7.34 & .034 & -.006 & -.019 \\
\hline CADES (France) & -.002 & .048 & 0.15 & 7.32 & .062 & .043 & -.055 \\
\hline ES sovereign & -.001 & .100 & -1.29 & 16.23 & .183 & -.004 & -.087 \\
\hline DE sovereign & -.002 & .055 & 0.05 & 5.22 & .004 & -.035 & -.021 \\
\hline FR sovereign & -.002 & .054 & 0.22 & 6.74 & .030 & -.010 & -.021 \\
\hline ES agency spread & .000 & .043 & 1.32 & 35.12 & -.263 & -.017 & -.062 \\
\hline DE agency spread & .000 & .024 & -0.26 & 13.11 & -.086 & -.045 & .018 \\
\hline FR agency spread & -.000 & .027 & -0.18 & 11.55 & -.086 & -.040 & -.048 \\
\hline
\end{tabular}

Note: Yields for each issuer are 5-year zero-coupon rates obtained by daily estimating Nelson-Siegel yield curves using Gimeno and Nave (2009) algorithm. Sample: from January $4^{\text {th }} 2008$ to December $31^{\text {st }} 2013$. 
In the case of the European debt crisis, episodes of flight to liquidity have been often proxied in the literature as a widening in the KfW yield spread over the German bund (e.g. Schwartz, 2010). While such a yield spread is easy to compute, its simplicity may unfortunately come at a cost in terms of economic interpretation of such episodes. ${ }^{4}$

This paper argues that a major shortcoming of focusing exclusively on the German bond market to identify FTL episodes over the last few years is that the nature of those FTS/FTL flows may have varied substantially as the sovereign debt crisis unfolded in euro area bond markets. Specifically, while in the early stages of the crisis FTS episodes involved a portfolio relocation between the then-considered riskier assets (equity, corporate bonds) and sovereign bonds, a crucial characteristic of the sovereign debt crisis in the euro area is that it also involved important portfolio reallocations within the euro area sovereign bond asset class.

Figure 4: Comovement between Spanish and German liquidity spreads during the crisis

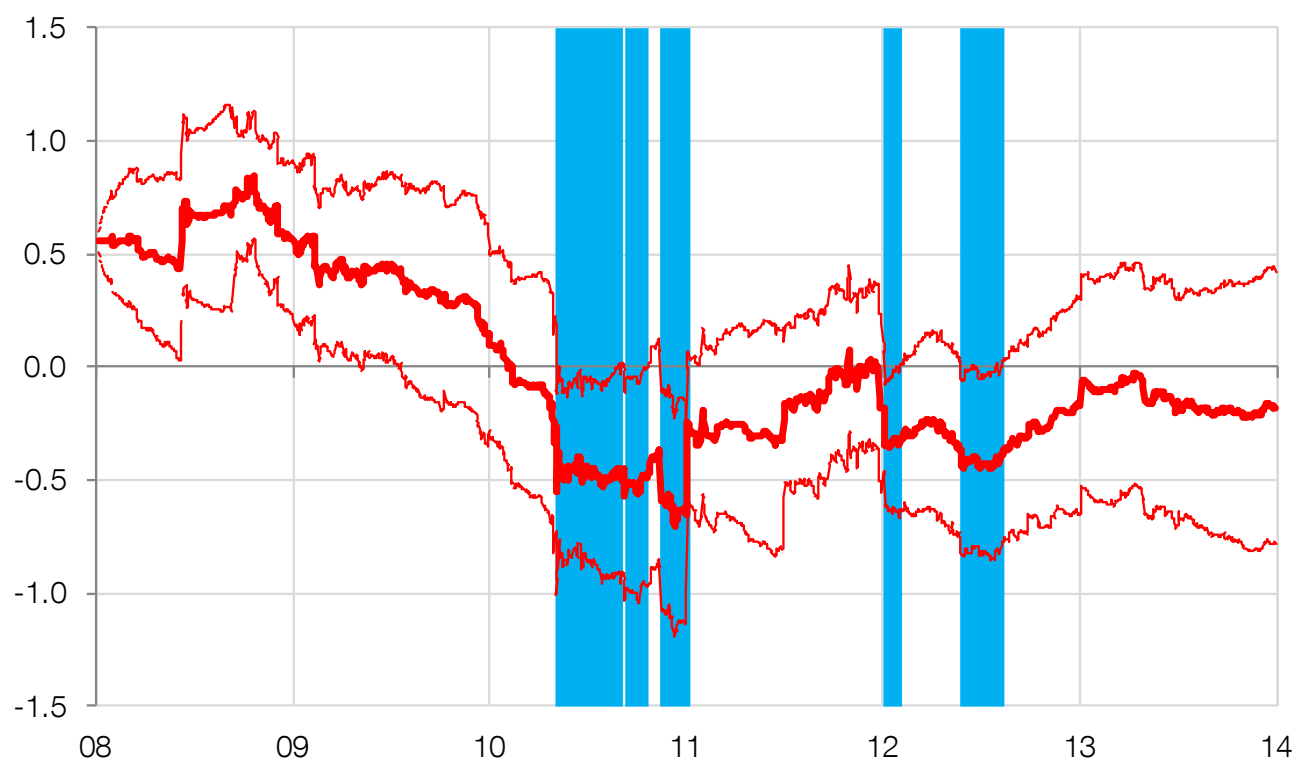

Shadows represent periods of statistically significant negative correlation based on a time-varying coefficient in a regression of changes in Spanish liquidity spread on changes in German ones. The solid line represents the estimated parameter, and the dotted lines the 95\% confidence intervals. Kalman filter parameters estimated: $\hat{\alpha}=-0.015 ; \hat{\sigma}_{v}=18.958 ; \hat{\sigma}_{w}=0.00058 ; \hat{\beta}_{0}=0.556$.

As an illustration, Figure 4 depicts the bivariate correlation between the agency spreads of Germany (as market destination of flight to liquidity flows) and Spain (as example of a country negatively affected by the sovereign debt crisis) since the beginning of the financial turbulences. We model such a comovement using a regression of the changes in sovereign liquidity spreads of one country as a function of the changes in the liquidity spread of a second country.

4. As an illustration in the Appendix, Figures $A 3$ and $A 4$ depict the identification of $F T L$ episodes based on relatively unusual daily widening of the $\mathrm{KfW}$ spread alone, and instances of joint $\mathrm{KfW}$ spread widening together with a decline in German bund yields. In both cases the result is a relatively large number of short-lived episodes since the beginning of the financial turbulences. 
$\Delta X_{t}^{s_{1}}=\alpha+\beta_{t} \Delta X_{t}^{S_{2}}+v_{t} \quad v_{t} \sim N\left[0, \sigma_{v}\right]$

where the relationship between both spreads $\left(\beta_{t}\right)$ is time varying, with the coefficients behaving as a random walk,

$\beta_{t}=\beta_{t-1}+w_{t} \quad w_{t} \sim N\left[0, \sigma_{w}\right]$

The resulting system is estimated by using standard Kalman filtering techniques.

Although the correlation started declining since late 2008, it remained significantly positive until late 2009. The intensification of the sovereign debt crisis in the euro area however pushed it into negative territory in early 2010 and a negative co-movement between German and Spanish agency spreads has remained broadly negative since then. Indeed, in statistical terms, this analysis suggests three protracted episodes of significant negative comovement in liquidity premium in German and Spanish bond markets between 2010 and 2013, only attenuated by the introduction of the Eurosystem long-term refinancing operations in late 2011 and thereafter by President Draghi's "whatever it takes to save the euro" pledge in the summer of 2012 (Draghi, 2012).

Those episodes of negative co-movement between German and Spanish agency spreads do suggest significant liquidity flows between both bond markets. Yet, it has to be taken into account that there was also a strong deterioration in Spanish public finances with the financial and economic crisis following the collapse of Lehman Brothers, and a FTS portfolio relocation from Spanish into German bonds would be observationally equivalent to a flight-to-liquidity episode.

The evolution of the co-movement between French and German agency spreads is also very telling about the deepening of the euro area debt crisis (see Figure A2). Indeed, although French sovereign bonds were not affected by the crisis to the same extend as the Spanish bonds in the early stages of the crisis, there was a protracted decline in the strength of the correlation between German and French agency spreads since early 2009, to the extent that by the Spring of 2012 it become significantly negative and only recovered after President Draghi's "whatever it takes" policy statement.

\subsection{Identifying flight to liquidity using a multivariate model}

Models where one of the agency spreads is a function of other of the agency spreads are necessarily descriptive and suffer from endogeneity problems, especially during the crisis, since both agency spreads are affected by what is happening to the other. Here we propose a more structural analysis where the three agency spreads are determined by a set of latent factors.

To better identify FTL episodes in euro area sovereign bond markets, we first look at the statistical properties of the three agency spreads available for the euro area. A principal component analysis suggests that two factors are enough to explain more than $95 \%$ of the variation in those three agency spreads (see Table 2). The principal-component analysis indicates that only one of the components has an eigenvalue greater than one. However, the second component retains a high level of explanatory power. Therefore, we have opted for a model with two latent factors that have the potential of explaining up to a $95 \%$ of the variability of the series. 
Table 2: Principal Component Eigenvalues and explained Variance of Spanish, German and French agency spreads

\begin{tabular}{ccccc}
\hline Component & Eigenvalue & Difference & Proportion & Cumulative \\
\hline Comp1 & 2.157 & 1.451 & 0.719 & 0.719 \\
Comp2 & 0.706 & 0.568 & 0.235 & 0.954 \\
Comp3 & 0.138 & & 0.046 & 1.000 \\
\hline
\end{tabular}

Table 2b: Eigenvectors for the Principal Component analysis

\begin{tabular}{ccccc}
\hline Variable & Comp1 & Comp2 & Comp3 & Unexplained \\
\hline ES & 0.462 & 0.872 & 0.164 & 0 \\
DE & 0.609 & -0.446 & 0.656 & 0 \\
FR & 0.645 & -0.203 & -0.737 & 0 \\
\hline
\end{tabular}

Note: Variables used in the Principal Component Analysis are daily time series (from January $4^{\text {th }} 2008$ to December $31^{\text {st }} 2013$ ) of the ICO Spread (ES, the difference between the 5-year zero-coupon rate of ICO and the equivalent Spanish Sovereign), KfW Spread (DE, the difference between the 5-year zero-coupon rate of KfW and the equivalent German Sovereign) and CADES Spread (the difference between the 5-year zero-coupon rate of CADES and the equivalent French Sovereign).

The eigenvectors of the principal components (Table 2b) suggests an important characteristic of the two components. The first one has similar loadings for all agency spreads and can be considered as the level factor, while the second one accounts for the heterogeneity among them. Therefore, we propose a two latent factors model, where the measurement equation is equal to:

$\left(\begin{array}{l}X_{t}^{E S} \\ X_{t}^{D E} \\ X_{t}^{F R}\end{array}\right)=\left(\begin{array}{l}\mu_{E S} \\ \mu_{D E} \\ \mu_{F R}\end{array}\right)+\left(\begin{array}{ll}\gamma_{1}^{E S} & \gamma_{2}^{E S} \\ \gamma_{1}^{D E} & \gamma_{2}^{D E} \\ \gamma_{1}^{F R} & \gamma_{2}^{F R}\end{array}\right)\left(\begin{array}{c}L_{1 t} \\ L_{2 t}\end{array}\right)+\left(\begin{array}{ccc}\sigma_{m} & 0 & 0 \\ 0 & \sigma_{m} & 0 \\ 0 & 0 & \sigma_{m}\end{array}\right)\left(\begin{array}{c}u_{t}^{E S} \\ u_{t}^{D E} \\ u_{t}^{F R}\end{array}\right)$

In this model, there are two latent factors. We have imposed the error terms $u_{t}^{j}$ to be uncorrelated, so shocks affecting more than one market would come from movements on the latent factors, while differences in agency spreads variability would rise from different sensibility to movements in the latent factors. In order to identify factors we have chosen that the coefficients for the German spread to be equal to $1\left(\gamma_{1}^{D E}=\gamma_{2}^{D E}=1\right)$, so the magnitude for both factors can be interpreted as the basis point impact of each factor into the German agency spread. If coefficients for the same factor are all positive (as we will show is the case for the first one, $L_{1 t}$ ), the factor can be interpreted as a common liquidity component, governing their joint behaviour, and therefore as a general preference for sovereign versus agency bonds. If the coefficients have values both positive and negatives, (as is the case of the second component, $L_{2 t}$ ), the corresponding factor would reflect the transfer of liquidity between sovereigns (liquidity premium changes that affects asymmetrically the different markets). Lastly, we let noise components $\left(u_{t}^{j}\right)$ to be uncorrelated, so common shocks to agency spreads will come through the noise components of the state equation.

We set the state equation for the latent factors to be equal to:

$\left(\begin{array}{l}L_{1 t} \\ L_{2 t}\end{array}\right)=\left(\begin{array}{ll}1 & 0 \\ 0 & 1\end{array}\right)\left(\begin{array}{l}L_{1 t-1} \\ L_{2 t-1}\end{array}\right)+\left(\begin{array}{cc}\sigma_{l_{1}} & 0 \\ 0 & \sigma_{l_{2}}\end{array}\right)\left(\begin{array}{l}v_{l_{1} t} \\ v_{l_{2} t}\end{array}\right)$

The model can therefore be considered as a filtering tool to isolate movements in agency spreads not (or at least less) related to market fears or sovereign credit risk that should be strongly associated to FTS flows captured by the first factor. The second factor would more directly capture the effects of FTL episodes. Specifically, as this factor moves German and Spanish liquidity spreads in opposite directions, its negative realisations capture a simultaneous widening of German spreads and a narrowing of Spanish spreads, consistent with the common understanding of a FTL away from Spanish sovereigns and into German bunds. Interestingly, the loadings of the second factor suggest that FTL episodes away from 
the Spanish bond market also took place in the early stages of the financial crisis, following the collapse of Bear Stearns in early 2008 and following Lehman collapse into the first months of 2009, well ahead of the intensification of the sovereign debt crisis in the euro area in 2010 and the downgrading of Spanish sovereign debt.

We set the matrix of coefficients in (7) to be diagonal. This is equivalent to rotate the factors to make them orthogonal. As can be seen in Figure 5, agency spreads move in line and divergences among them seem to revert in time. Thus, we have opted to set both factors to be a random walk, so shocks are considered to be permanent. Alternative specifications where we let coefficients in equation (7) to be different from one produce values close to the unity. Using a standard Kalman Filter approach to estimate the latent factors, the results are shown in Table 3.

Figure 5: Latent factors of the liquidity model
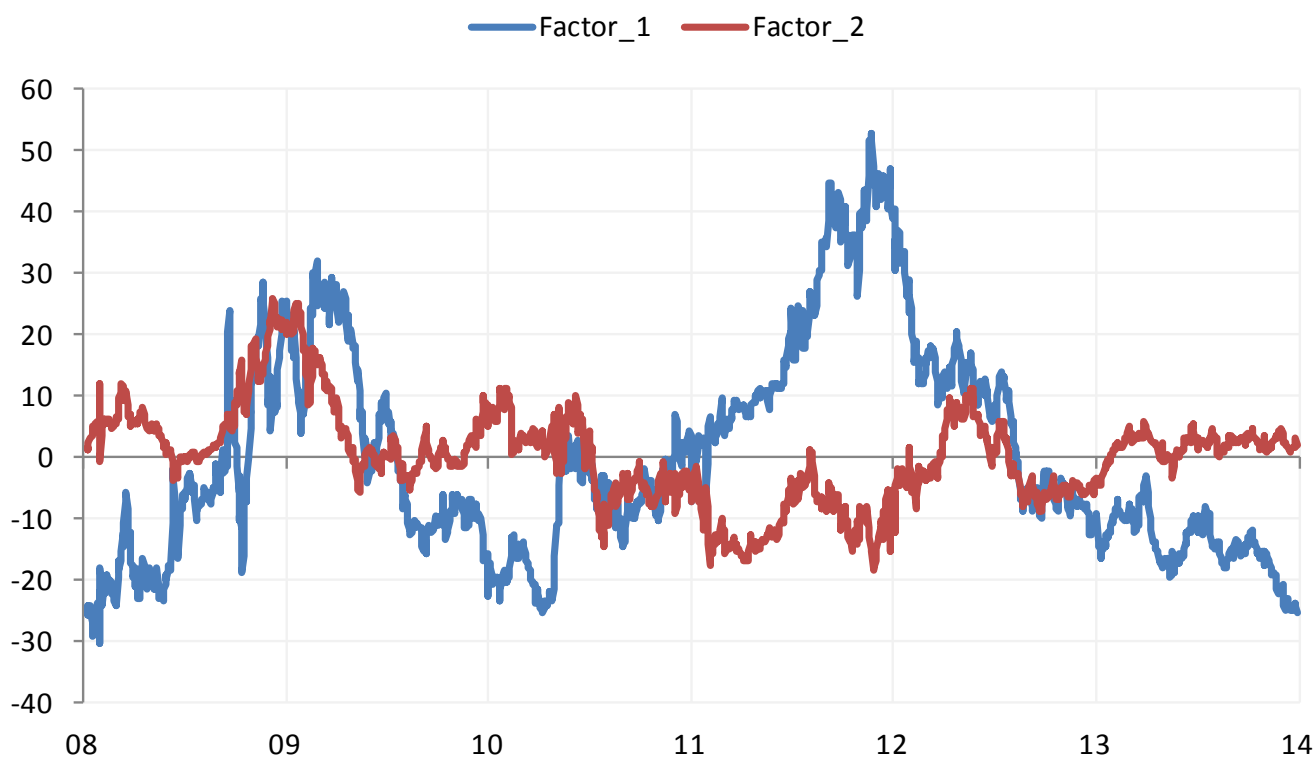

Note: Latent factors obtained from a Kalman Filter estimate of the Dynamic Factor Model proposed in equations 6-7. Observed variables are French, Spanish and German agency spreads from January 2008, to December 2013.

Similarly to the results obtained for the principal components analysis, we get a first factor with similar coefficients for the three agency spreads, whereas the second factor has an opposite sign for Spain versus Germany and France. In figure 5, we can observe the estimated evolution of each factor.

The first factor strongly increases both around the Lehman Brothers crisis (2008Q42009Q1), and also around the euro area sovereign debt crisis (being at is maximum in the second half of 2011, just before the beginning of the VLTROs-Very Long Term Refinancing Operations-). In fact, this factor has a very similar evolution to measures of market risk or fear, as for example the VSTOXX volatility index for the EUROSTOXX 50 index, the equivalent to the VIX index for the US market (see Figure 6). This evidence lends support to our interpretation of the first factor as capturing FTS flows. 
Table 3: Dynamic latent factor model estimation.

\begin{tabular}{llll} 
& \multicolumn{3}{c}{ Measurement equation } \\
\cline { 2 - 4 } & ES & DE & FR \\
\hline$\mu$ & 33.60 & 41.18 & 21.54 \\
$\gamma_{1}$ & 0.90 & 1.00 & 0.60 \\
$\gamma_{2}$ & -1.84 & 1.00 & 0.28 \\
$\sigma$ & 2.30 & 0.65 & 6.07 \\
\hline
\end{tabular}

\begin{tabular}{ccc} 
& \multicolumn{2}{c}{ State Equation } \\
\cline { 2 - 3 } & $\mathrm{F}_{1}$ & $\mathrm{~F}_{2}$ \\
\hline$\varphi$ & 1 & 1 \\
$\sigma_{\mathrm{f}}$ & 1.91 & 1.22 \\
\hline
\end{tabular}

Note: Dynamic latent factor model proposed in equation 6 (Measurement equation) and 7 (State equation). Variables used are daily time series (from January $4^{\text {th }} 2008$ to December $31^{\text {st }}$ 2013) of the ICO Spread (ES, the difference between the 5-year zero-coupon rate of ICO and the equivalent Spanish Sovereign), KfW Spread (DE, the difference between the 5-year zero-coupon rate of $\mathrm{KfW}$ and the equivalent German Sovereign) and CADES Spread (the difference between the 5-year zerocoupon rate of CADES and the equivalent French Sovereign).

By contrast, the second factor provides signals of liquidity differentiation between countries both in the aftermath of the Lehman Brothers collapse and also in mid-2012, when a financial support programme for the Spanish economy was in consideration given the significant deterioration of bond market conditions. We therefore interpret this factor as providing evidence on the impact of more genuine FTL flows beyond and above liquidity effects stemming from FTL flows. Therefore, this second factor underpins our identification of FTL episodes and is the starting point for our investigation of the quantitative effects of those episodes on several financial and macroeconomic variables. It is important to note, however, that by controlling by the liquidity effects of FTS flows by mean of the first latent factor, our investigation is likely to provide a lower bound on the liquidity premium in those financial instruments.

Figure 6: Risk aversion (First latent) factor and ITRAXX index.

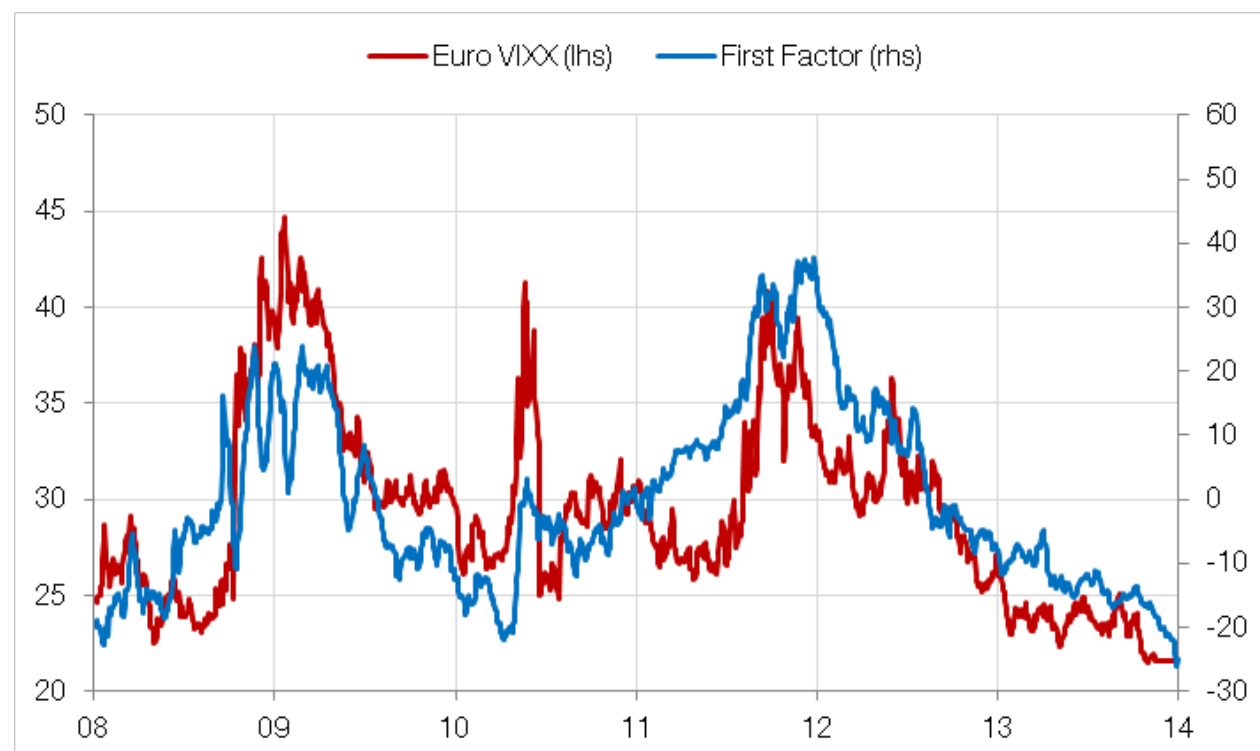

Blue line (right-hand-side) represents the first latent factors obtained from the Kalman Filter estimate of the Dynamic Factor Model proposed in equations 6-7 (French, Spanish and German 5-year agency spreads as observed variables). Red line represents the VIXX volatility index for the EuroStoxx for the larger maturity available ( 24 months) for a better match with the maturity of the agency spreads. 
This section documents the impact of FTL flows on different financial and economic indicators. The purpose is to characterise FTL episodes identified using the factor model introduced in the previous section rather than to look for causality. In particular, an important aspect of our analysis here is to analyse the behaviour of those variables across most euro area bond markets and not only in the three major ones for which agency spreads are available.

We first focus in detail on euro area sovereign bond markets. We will report our regression results for the three countries for which we have computed the agency spreads, namely Spain, Germany and France, and also Italy, the other large bond market in the euro area,. Our tables will also provide summary statistics (average, standard deviation and max/min values) of the impact of FTL flows for two euro area country groups: (i) "core" countries (Austria, Belgium, Finland, France, Germany and Netherlands) and (ii) "stressed" countries (Greece, Ireland, Italy, Portugal and Spain), whose sovereign debt was more seriously affected by the market turbulences and that eventually was subject to the Eurosystem Securities Market Programme (SMP).

\subsection{Sovereign bond markets during FTL episodes}

Table 4 provides evidence of the effects of FTL episodes on euro area sovereign bond markets. Before discussing our results some considerations are worth bearing in mind. We will report results for the zero-coupon yields at the 2, 5 and 10-year maturities. While zerocoupon term structures are necessary to compute the liquidity spreads for Spain, Germany and France, it is worth noting that the estimation of those zero-coupon term structures imply some fitting errors that may convey important information on liquidity. Recent literature has shown that such fitting errors contain information about the liquidity premia in the underlying bonds used in the estimation (see Hu et al., 2013, Berenguer et al., 2013). To the extent that fitted yields are likely to be partially deprived from liquidity premia content, our quantitative findings are likely to be biased downwards.

As a robustness exercise, we also consider the yields of benchmark sovereign bonds (by Bloomberg) for each maturity. Although on-the-run premia effects seem to be weaker in the euro area than in the US market, those bonds are likely to remain somewhat more liquid than the off-the-run ones, so if anything, their use in our analysis should also tend to bias the analysis against a significant liquidity deterioration and, therefore, our empirical findings should be interpreted as a low estimate of such a deterioration.

Finally, our purpose is to analyse the impact of $F L$ flows in all euro area bond markets. Since sovereign bond yields of some euro area countries were particularly volatile and exhibited signals of (local) non-stationarity in our sample, we report results for regressions both in levels and first differences.

The regressions results reported in Table 4 Panel A point to significant increases in the levels of Spanish bond yields, and decreases in German and French sovereign bond yields, which corresponds to the basic intuition between FTL flows among those bond markets. Importantly, these qualitative findings hold not only for the three countries for which we can compute the agency spreads but also for the country blocks they represent. Indeed, 
our regression results suggest significant changes in sovereign yields in opposite directions reflecting strong portfolio relocation flows from stressed to core bond markets within the euro area. For example, our results also suggest significant increases in the other large sovereign bond markets under stress during the crisis, Italy, with the impact being somewhat stronger at longer maturities. Average results and standard deviations of the impact estimates for all stressed countries are significantly higher than those reported for Italy and Spain, which suggest that FTL flows were particularly adverse for smaller and more seriously stressed bond markets.

Table 4: Impact of flight to liquidity on sovereign bond markets: yields and trading activity

\begin{tabular}{|c|c|c|c|c|c|c|c|c|c|c|c|c|c|c|}
\hline \multirow[b]{3}{*}{ Impact on yiel } & \multirow[b]{2}{*}{ ES } & \multirow[b]{2}{*}{$\mathrm{DE}$} & \multirow[b]{2}{*}{ FR } & \multirow[b]{2}{*}{ IT } & \multicolumn{4}{|c|}{ CORE (DE, FR, AT, BE, NL, FI) } & \multirow[b]{2}{*}{ SIG. } & \multicolumn{4}{|c|}{ STRESSED (ES, IT IE PT GR) } & \multirow[b]{2}{*}{ SIG. } \\
\hline & & & & & MEAN & STD & $\mathrm{MIN}$ & MAX & & MEAN & STD & $\mathrm{MIN}$ & MAX & \\
\hline & & & & & & & & & & & & & & \\
\hline \multicolumn{15}{|c|}{ Panel A: levels } \\
\hline \multicolumn{15}{|c|}{ Zero-coupons } \\
\hline 2-year & $-1.517^{* * *}$ & $3.099 * * *$ & $2.958 * * *$ & $-0.552^{* *}$ & 3,415 & 1,070 & 1,617 & 5,044 & 6 & $-31,610$ & 49,171 & $-129,282$ & $-0,552$ & 5 \\
\hline 5-year & $-2.367^{* * *}$ & $2.692^{* * *}$ & $2.466 * * *$ & $-0.868 * * *$ & 2,625 & 0,747 & 1,076 & 3,301 & 6 & $-16,250$ & 17,408 & $-49,103$ & $-0,868$ & 5 \\
\hline 10-year & $-3.476 * * *$ & $2.399 * * *$ & $1.881^{* * *}$ & $-1.439 * * *$ & 2,232 & 0,756 & 0,726 & 2,973 & 6 & $-10,161$ & 7,520 & $-22,477$ & $-1,439$ & 5 \\
\hline \multicolumn{15}{|c|}{ Benchmark bonds } \\
\hline 2-year & $-1.934 * * *$ & $2.887^{* * *}$ & $2.976 * * *$ & $-0.746 * * *$ & 2,634 & 0,948 & 0,750 & 3,504 & 6 & $-35,449$ & 51,366 & $-136,944$ & $-0,746$ & 5 \\
\hline 5-year & $-2.812^{* * *}$ & $2.538^{* * *}$ & $2.490 * * *$ & $-1.106^{* * *}$ & 2,686 & 0,854 & 1,034 & 3,651 & 6 & $-18,108$ & 19,120 & $-54,050$ & $-1,106$ & 5 \\
\hline 10-year & $-3.488^{* * *}$ & $2.074^{* * *}$ & $1.907^{* * *}$ & $-1.374^{* * *}$ & 2,233 & 0,813 & 0,674 & 2,976 & 6 & $-13,685$ & 12,430 & $-36,407$ & $-1,374$ & 5 \\
\hline \multicolumn{15}{|c|}{ Panel B: First differences } \\
\hline \multicolumn{15}{|c|}{ Zero-coupons } \\
\hline 2-year & $0.966 * * *$ & -0.141 & 0.036 & $0.986 * * *$ & 0,006 & 0,137 & $-0,141$ & 0,283 & 0 & 1,163 & 0,447 & 0,853 & 2,053 & 3 \\
\hline 5-year & $1.053^{* * *}$ & $-0.223^{*}$ & 0.080 & $1.010^{* * *}$ & 0,033 & 0,195 & $-0,223$ & 0,395 & 1 & 2,263 & 2,203 & 1,010 & 6,650 & 3 \\
\hline 10-year & $0.789 * * *$ & $-0.299 * *$ & 0.022 & $0.807^{* * *}$ & $-0,020$ & 0,198 & $-0,299$ & 0,341 & 2 & 0,382 & 1,665 & $-2,860$ & 1,805 & 3 \\
\hline \multicolumn{15}{|c|}{ Benchmark bonds } \\
\hline 2-year & $1.616^{* * *}$ & 0.111 & 0.026 & $0.993 * * *$ & 0,183 & 0,180 & 0,026 & 0,568 & 1 & 11,076 & 17,244 & 0,993 & 45,484 & 5 \\
\hline 5-year & $1.264 * * *$ & 0.068 & $0.262^{* *}$ & $0.987^{* * *}$ & 0,289 & 0,175 & 0,068 & 0,536 & 3 & 3,527 & 3,145 & 0,987 & 9,497 & 5 \\
\hline 10-year & $0.669 * * *$ & -0.070 & $0.211^{*}$ & $0.609 * * *$ & 0,184 & 0,167 & $-0,070$ & 0,468 & 2 & 2,220 & 1,915 & 0,609 & 5,789 & 5 \\
\hline \multicolumn{15}{|c|}{ Impact on trading activity } \\
\hline $\begin{array}{l}\text { Order-flow } \\
\text { (buys-sells) }\end{array}$ & $-146.842^{* * *}$ & $72.352^{* *}$ & $-167.054^{* *}$ & 58.356 & 20,869 & 128,024 & $-167,054$ & 254,873 & 3 & $-14,111$ & 71,138 & $-146,842$ & 58,356 & 1 \\
\hline
\end{tabular}

Note: Each row in the table represents the linear regression estimates where the regressed variable is reported in the first column. In all cases, the regressors are the two factors of the Dynamic Factor Model (equations 6-7), although only the coefficient of the second one (Flight to Liquidity factor) is reported. We perform separate estimations for each country. Columns 2-5 report the estimations for the top 4 bond markets in the euro area. Columns 6-10 report mean, minimum, maximum as well as standard deviations of the coefficients estimated for those countries labelled core (Germany, France, Austria, Belgium, The Netherlands, and Finland), where the last column $\left(10^{\text {th }}\right)$ is the number of regressions where this coefficient is statistically significant at a $5 \%$ level. Columns 11-15 report mean, minimum, maximum as well as standard deviations of the coefficients estimated for those countries labelled stressed (Spain, Italy, Ireland, Portugal, Greece), where the last column $\left(15^{\text {th }}\right)$ is the number of regressions where this coefficient is statistically significant at a $5 \%$ level. . Robust standard errors are used for the computation of the statistical tests.

By contrast, the level of sovereign bond yields of all core euro area countries did exhibit significant decreases during FTL episodes, in line with the results for Germany and France. The average impact for all core markets as a whole is somewhat lower than for Germany, but smaller bond markets also benefited from those inflows and the standard deviation of the estimated effects suggests less heterogeneity than for the stressed countries. Those qualitative findings seem to be quite robust across yield measures. On average, the sign and magnitude of the estimated coefficients using yield levels for benchmark bonds are broadly in line with those for the zero-coupon yields, as discussed above if anything somewhat higher as should be expected. 
Table 4 Panel B results on first differences also suggest strong significant increases in sovereign bond yields for stressed countries, in theory those whose behaviour tends to exhibit a stronger upward trend and more symptoms of non-stationarity. The influence of FTL flows during the financial crisis in the euro area is also quantitatively important: for Spain it suggests a variation in 5-year sovereign yields of almost 80 basis points and around 60 basis points for Italian bond yields. In contrast, overall, the significance of the estimates drops for daily changes in the more stable bond yields of the core countries.

\subsubsection{TRADING ACTIVITY IN BOND MARKETS.}

Finally, we investigate the extent to which our FTL episodes also have an impact in bond trading activity that justifies those effects in sovereign bond yields. Unfortunately global trading activity in euro area bond markets is not available at daily frequency. We therefore employ order-flow (buy minus sell volumes) of transactions within the MTS interdealer market, by far the largest electronic trading system for the euro area bond market and has been already employed in several studies of the euro area bond market (e.g. Beber et al., 2009). 5 Bond trading through the MTS system can take place on two different platforms, the pan-European EuroMTS and the domestic (national) ones. In its early years, the EuroMTS was the reference electronic market for euro benchmark bonds and those with a minimum outstanding value of EUR5bn, while the domestic (national) MTS platforms allowed for trading of all remaining sovereign bonds of euro area countries, but MTS gradually evolved to a symmetric dualplatform trading system from 2006. Our empirical work is based on trading statistics consolidated across platforms. Despite those considerations, it has to be borne in mind that MTS market share differs across euro area countries, ranging even within the largest ones from being very high for Italy but much lower for Germany for instance, which may influence our results.

We find that trading activity is also significantly affected by FTL episodes, as reflected in order-flow activity in bond markets. FTL episodes are associated to negative changes in order-flow for stressed bond markets, for example Spain, suggesting an asymmetry in trading activity towards sell orders in those markets which is consistent with the upward pressure on bond yields we reported above. Furthermore, we also find a negative impact of FTL on orderflow in all stressed countries. In this regard, the significance and magnitude of the coefficient for Italy is particularly important, for, as discussed above, the MTS share of overall trading activity in Italian bonds is particularly high. In contrast, the FTL impact on order-flow in core bond markets is, on average, positive although results do reflect some heterogeneity probably related to the differences in MTS share across countries that may explain the low significance of the estimated impacts.

\subsection{Stock market performance during FTL episodes}

To assess the behaviour of stock markets during FTL episodes, we regress daily returns of the overall market and 10 different industry-specific portfolios (using the Datastream industry classification) on the two factors in our model, the FTS factor and our FTL factor. In addition, as stressed in Baele et al. (2013) it is important to note that the coefficient on FTL must be interpreted as an abnormal return during FTL episodes, but it does not indicate which portfolios perform best or worst during FTL episodes spells, as portfolios with positive (negative) FTL betas may have also high (low) market betas.

5. MTS-system market share among the electronic trading systems in Europe was already $74 \%$ of daily average turnover in 2003, and has been further developed since them. 
Table 5: Impact of flight to liquidity and flight to safety on stock markets

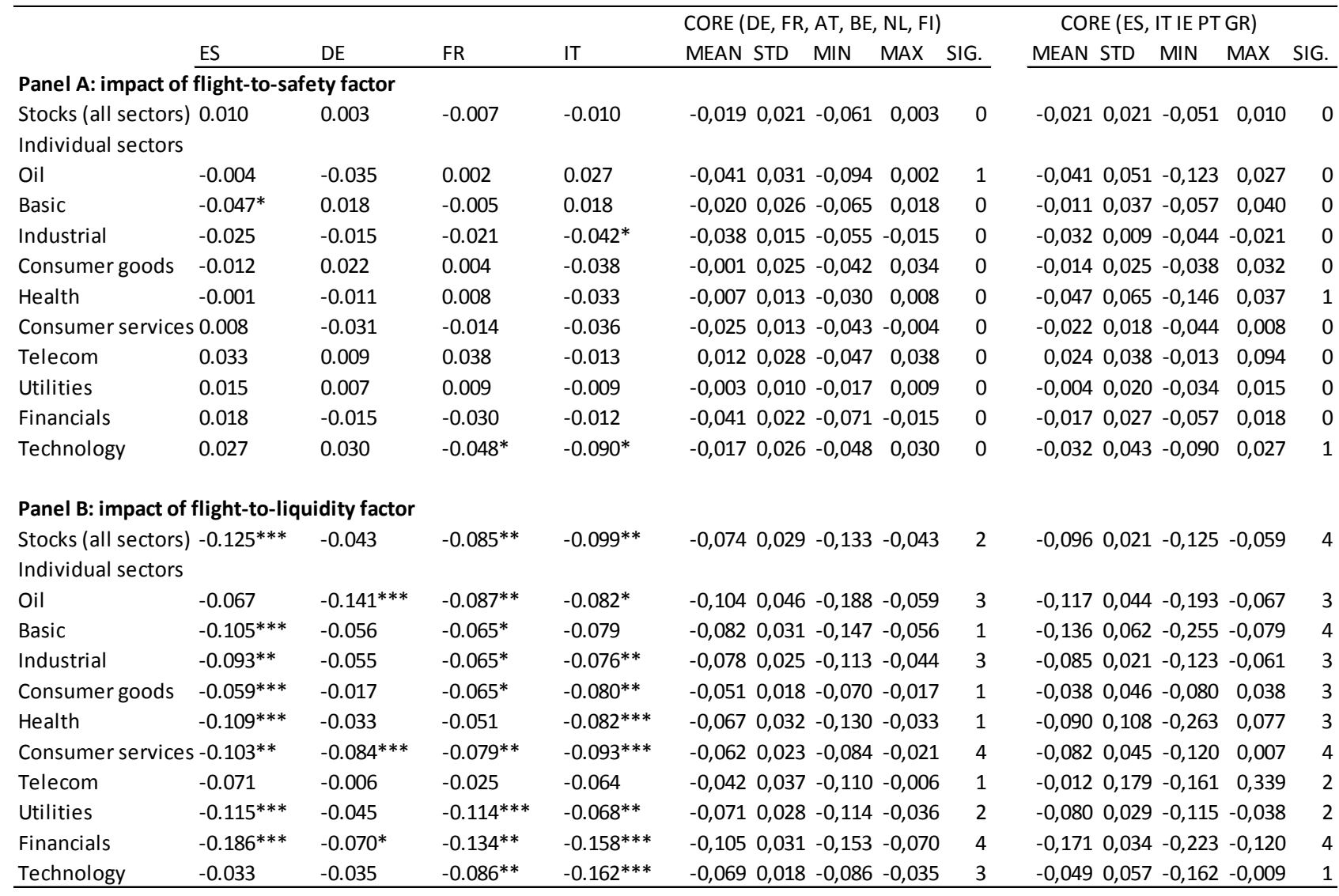

Note: Each row in the table represents the linear regression estimates where the regressed variable is reported in the first column. In all cases, the regressors are the two factors of the Dynamic Factor Model (equations 6-7). Panel A shows the estimated coefficient of the first factor (flight-to-liquidity factor), and Panel B shows the estimated coefficient of the second one (Flight to Liquidity factor). We perform separate estimations for each country. Columns 2-5 report the estimations for the top 4 bond markets in the euro area. Columns 6-10 report mean, minimum, maximum as well as standard deviations of the coefficients estimated for those countries labelled core (Germany, France, Austria, Belgium, The Netherlands, and Finland), where the last column $\left(10^{\text {th }}\right)$ is the number of regressions where this coefficient is statistically significant at a $5 \%$ level. Columns $11-15$ report mean, minimum, maximum as well as standard deviations of the coefficients estimated for those countries labelled stressed (Spain, Italy, Ireland, Portugal, Greece), where the last column $\left(15^{\text {th }}\right)$ is the number of regressions where this coefficient is statistically significant at a $5 \%$ level. . Robust standard errors are used for the computation of the statistical tests.

Table 5 results indicate that FTL episodes during the euro area financial and debt crisis had a negative impact on stock markets, as stocks were indeed perceived as riskier assets during those episodes. Furthermore, in contrast to bond markets, the fact that both core and stressed countries' stock markets display significantly negative daily returns on those days highlights the importance of accounting for such episodes to understand developments in euro area financial markets as a whole.

At sector level, we find that the performance of most if not all sectors are significantly and adversely affected by FTL flows. Moreover, qualitative results hold for most if not all countries, and our results do not suggest any specific defensive sector in the event of such episodes. The standard deviation of the estimated impact coefficients across countries displays some strong variation across sectors but this may be related to the different weight of specific sectors across countries and the size of the stock markets.

\subsection{Economic confidence and FTL episodes}

The FTL episodes we identified in our analysis also coincide with a deepening of the economic crisis in many euro area countries. Although we identified FTL episodes using bond 
market data only, the results in the previous section showed that the impact of FTL episodes was also significant on stock markets. This section explores the extent to which those episodes also affected confidence in the euro area economies and not only in financial markets.

To investigate the contemporaneous relationship between the financial and the real economy dimensions of the crisis, in Table 6 we report results of regressions of changes in monthly indicators of consumer and economic confidence on the average of our FTL factor in the previous month to their release. We find strong evidence that the financial market turbulence associated to the FTL episodes were an important determinant of the deterioration in economic confidence. Importantly, as for the stock market, FTL episodes led to lower confidence in all euro area countries, both core and stressed, and not only in those whose bond markets were adversely affected by the liquidity outflows. Moreover, Table 6 shows that the associated confidence deterioration among euro area consumers is robust to the use of alternative indicators, which suggests that FTL episodes were interpreted as a signal of a deepening of the economic crisis in the euro area as a whole. We also report results for the FTS factor as such episodes are often link to negative returns in the stock market corroborating the findings in Baele et al. (2013), which stress the importance of accounting for the effects of these turbulences in financial markets on the real economy.

Table 6: Impact of flight to liquidity and flight to safety factors on economic and consumer confidence

\begin{tabular}{|c|c|c|c|c|c|c|c|c|c|c|c|c|c|c|}
\hline & \multirow[b]{2}{*}{ ES } & \multirow[b]{2}{*}{$\mathrm{DE}$} & \multirow[b]{2}{*}{$F R$} & \multirow[b]{2}{*}{ IT } & \multicolumn{4}{|c|}{ CORE (DE, FR, AT, BE, NL, FI) } & \multirow[b]{2}{*}{ SIG. } & \multicolumn{4}{|c|}{ CORE (ES, IT IE PT GR) } & \multirow[b]{2}{*}{ SIG. } \\
\hline & & & & & MEAN & STD & $\mathrm{MIN}$ & MAX & & MEAN & STD & MIN & MAX & \\
\hline \multicolumn{15}{|c|}{ Panel A: impact of flight-to-safety factor } \\
\hline OECD Economic Sentiment & $-14.791 * * *$ & $-15.054 * * *$ & $-16.511 * * *$ & $-18.322^{* * *}$ & $-19,287$ & 3,630 & $-24,821$ & $-15,054$ & 6 & $-22,787$ & 6,385 & $-29,908$ & $3-14,791$ & 4 \\
\hline EC Consumer Confidence & $-0.953^{*}$ & -1.306 & $-1.589 * * *$ & $-2.709 * * *$ & $-2,307$ & 1,438 & $-5,360$ & $-1,113$ & 6 & $-9,409$ & 14,529 & $-38,440$ & $-0,953$ & 3 \\
\hline \multicolumn{15}{|c|}{ Panel B: impact of flight-to-liquidity factor } \\
\hline OECD Economic Sentiment & $-44.837 * * *$ & $-98.461 * * *$ & $-66.846 * * *$ & $-42.558 * * *$ & $-75,310$ & 12,134 & $-98,461$ & $-65,963$ & 6 & $-20,543$ & 24,801 & $1-44,837$ & 15,124 & 3 \\
\hline EC Consumer Confidence & $-7.746 * * *$ & $-12.832 * * *$ & $-2.581 * * *$ & 0.386 & $-7,041$ & 3,686 & $-12,832$ & $-2,581$ & 6 & 20,078 & 39,905 & $5-7,746$ & 599,383 & 3 \\
\hline
\end{tabular}

Note: Each row in the table represents the linear regression estimates where the regressed variable is reported in the first column. In all cases, the regressors are the two factors of the Dynamic Factor Model (equations 6-7), although only the coefficient of the second one (Flight to Liquidity factor) is reported. We perform separate estimations for each country. Columns 2-5 report the estimations for the top 4 bond markets in the euro area. Columns 6-10 report mean, minimum, maximum as well as standard deviations of the coefficients estimated for those countries labelled core (Germany, France, Austria, Belgium, The Netherlands, and Finland), where the last column $\left(10^{\text {th }}\right)$ is the number of regressions where this coefficient is statistically significant at a $5 \%$ level. Columns 11-15 report mean, minimum, maximum as well as standard deviations of the coefficients estimated for those countries labelled stressed (Spain, Italy, Ireland, Portugal, Greece), where the last column $\left(15^{\text {th }}\right)$ is the number of regressions where this coefficient is statistically significant at a $5 \%$ level. Robust standard errors are used for the computation of the statistical tests. 
Table 7: Impact of flight to liquidity and flight to safety factors on asset swap spreads

\begin{tabular}{lcc}
\hline & \multicolumn{2}{c}{$\begin{array}{c}\text { flight-to-safety } \\
\text { flight-to-liquidity } \\
\text { factor }\end{array}$} \\
\cline { 2 - 3 } BofA Merrill Lynch Asset Swap Spread Index & & \\
Euro Area Non-Financial & 0.054 & $0.097^{*}$ \\
Euro Area Financial & $0.113^{* * *}$ & $0.162^{* * *}$ \\
Euro Area Government & -0.026 & $1.222^{* * *}$ \\
Periphery Non-Financial & $0.066^{* *}$ & $0.185^{* * *}$ \\
Periphery Financial & $0.106^{* * *}$ & $0.196^{* * *}$ \\
Periphery Government & 0.276 & $1.032^{* * *}$ \\
Non-Periphery Non-Financial & 0.044 & $0.089^{*}$ \\
Non-Periphery Financial & $0.114^{* * *}$ & $0.158^{* * *}$ \\
Non_Periphery Government & -0.631 & 0.010 \\
\hline
\end{tabular}

Note: Each row in the table represents the linear regression estimates where the regressed variable is reported in the first column. In all cases, the regressors are the two factors of the Dynamic Factor Model (equations 6-7). Regressions are estimated in differences for both the Asset Swap Spreads and the factors, and robust standard errors are used for the computation of the statistical tests. 


\section{Concluding remarks}

By comparing sovereign and agency bonds (bonds with identical level of credit risk but different levels of liquidity), this paper analysed liquidity premia in three major euro area sovereign bond markets (Spain, Germany and France) between 2008 and 2013. We showed that such liquidity spreads reached more than 100 basis points during the euro area debt crisis, and identified flight to liquidity episodes above and beyond "flight to quality" or "flight to safety" spells.

We then showed that accounting for flight to liquidity episodes is an essential element for a thorough understanding of developments in euro area bond markets in recent years. First, flight to liquidity flows contributed to explain the significant widening of intra-euro area sovereign spreads by increasing the yields of the bonds from stressed countries while at the same time lowering those from core countries. In addition, we showed that flight to liquidity episodes were associated with stock market declines and confidence deterioration in the euro area as a whole, that is, not only in stressed but also in core countries, and thereby aggravating the financial and economic crisis.

The strong effects of flight to liquidity flows that we find in this paper suggest at least two areas for further research. First, a more thorough understanding of their effects in other market segments, like for example corporate bond markets, and the macroeconomy, for example on growth expectations, is important and such extensions of our analysis are already in our agenda.

Our results also show that the effects of flight to liquidity episodes on bond and other financial markets are important for policy makers. Indeed, the timing and goals of some of the policy measures taken during the euro area debt crisis could be better understood by the intensity of flight to liquidity episodes. Assessing the impact of such measures, for example the sovereign bond purchases under the Securities Market Programme of the Eurosystem, on attenuating flight to liquidity episodes is another important avenue to explore. In this field, the original analyses of Eser and Schwaab (2013) and Ghysels et al. (2013) are seminal and the factors proposed in our paper could be added to their methodology to assess the improvements in liquidity of the SMP programme. 
BAELE, L. G. BEKAERT, K. INGHELBRECHT and M. WEI (2012). Flights to safety, NBER Working Paper No. 19095 May.

BEBER, A., M. W. BRANDT, and K. A. KAVAJECZ (2009). Flight-to-quality or flight-to-liquidity? Evidence from the euroarea bond market, Review of Financial Studies 22, 925-957.

BERENGUER, E., R. GIMENO, and J. NAVE (2013). Term structure estimation, liquidity-induced heteroskedasticity and the price of liquidity risk, Banco de España Working Paper No.1308.

BIS (2005). Zero-coupon yield curves: technical documentation, Bank for International Settlements Papers, No. 25 Basel.

BRUNNERMEIER, M. K., and L. H. PEDERSEN (2009). Market liquidity and funding liquidity, Review of Financial Studies 22, 2201-2238

CABALLERO, R. J., and A. KRISHNAMURTHY (2008). Collective risk management in a flight to quality episode, Journal of Finance 63, 2195-2230.

DRAGHI, M. (2012). Speech by Mario Draghi, President of the European Central Bank at the Global Investment Conference in London, 26 July. http://www.ecb.europa.eu/press/key/date/2012/html/sp120726.en.html

EJSING, J., GROTHE, M. and GROTHE, O. (2012). Liquidity and Credit Risk Premia in Government Bond Yields, ECB Working Paper Series No. 1440.

ESER, F. and B. SCHWAAB (2013). Assessing asset purchases within the ECB's securities markets programme, ECB Working Paper Series No. 1587.

GHYSELS, E., J. IDIER, S. MANGANELLI and O. VERGOTE (2013). A high frequency assessment of the ECB securities markets programme, CEPR working paper No. 9778

HU G. X, J. PAN and J. WANG (2013). Noise as Information for Illiquidity, Journal of Finance, 68, 2223-2772,

GIMENO, R. and NAVE, J.M. (2009). A genetic algorithm estimation of the term structure of interest rates, Computational Statistics \& Data Analysis 53(6), 2236-2250

LONGSTAFF, F.A. (2004). The Flight-to-Liquidity Premium in U.S. Treasury Bond Prices, Journal of Business, 77(3), 511 526.

MONFORT, A., and RENNE, J. P. (2013). Default, liquidity, and crises: An econometric framework, Journal of Financial Econometrics, 11(2), 221-262.

MONFORT, A., and RENNE, J. P. (2013). Decomposing Euro-Area Sovereign Spreads: Credit and Liquidity Risks, Review of Finance, forthcoming.

NELSON, C.R., and SIEGEL, A.F. (1987). Parsimonious Modelling of Yield Curves, Journal of Business 60 (4), 473-489.

Schwarz, K. (2010). Mind the gap: disentangling credit and liquidity in risk spreads, mimeo, University of Pennsylvania, October.

VAYANOS, D. (2004). Flight to quality, flight to liquidity, and the pricing of risk, Working Paper. 
Figure A1: Yield curve of ICO and Spanish Sovereign bonds

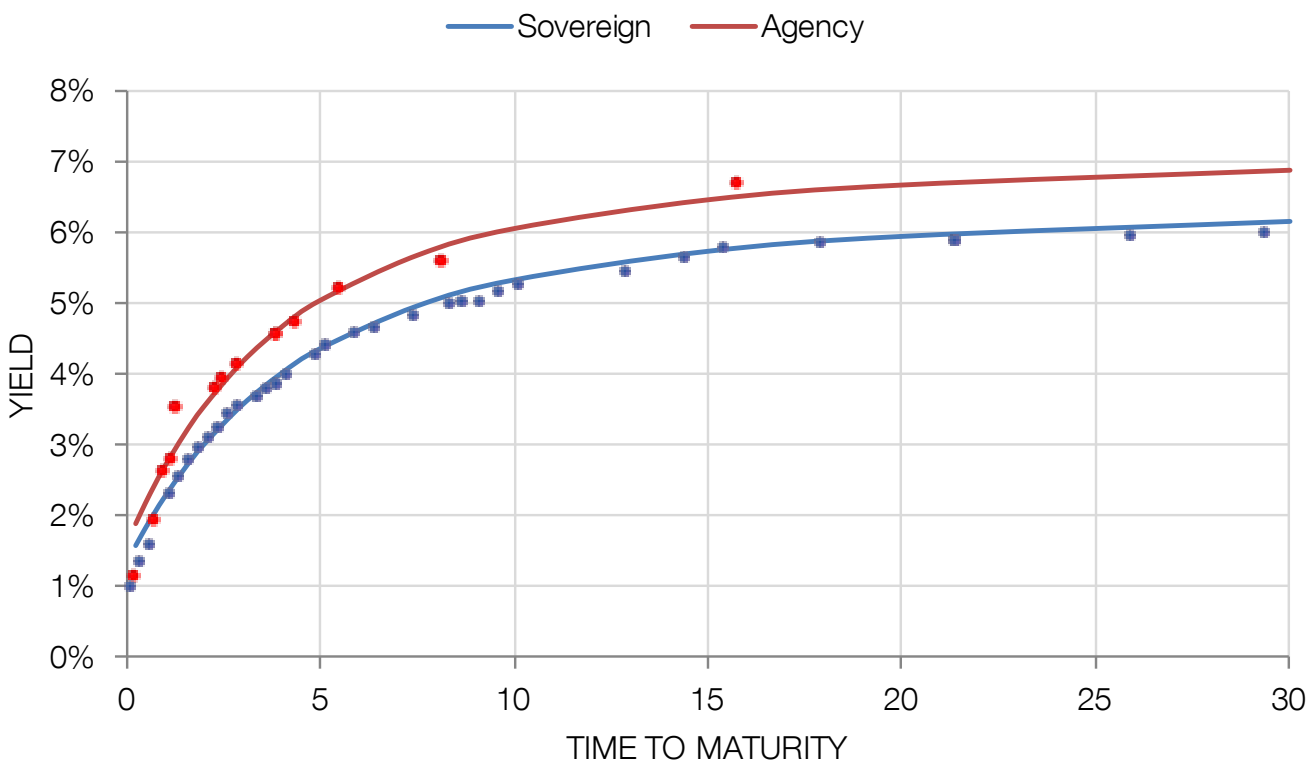

Note: Red dots represent yield and time to maturity of Spanish sovereign bonds; Blue dots represent yields and time to maturity of ICO bonds, while continuous lines represent the zero-coupon Nelson-Siegel yield curves. All data corresponds to the $01 / 04 / 2011$

Figure A2: Time variant coefficient in the regression between daily changes in French and German liquidity spreads

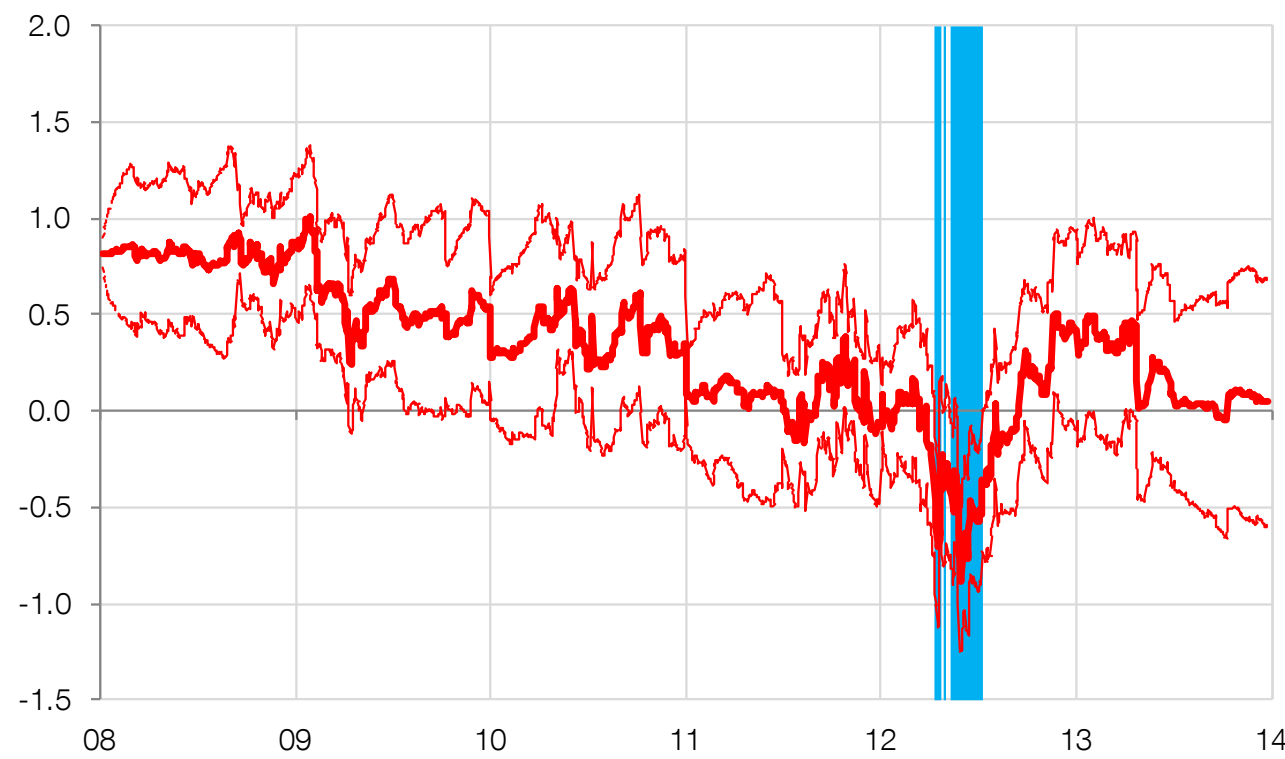

Shadows represent periods of statistically significant negative correlation. The solid line represents the estimated parameter, and the dotted lines the 95\% confidence intervals. Kalman filter parameters estimated: $\hat{\alpha}=-0.019 ; \hat{\sigma}_{v}=6.366 ; \hat{\sigma}_{w}=0.0006$ $\hat{\beta}_{0}=0.820$ 
Table A.1: ICO Bonds used for the estimation of the yield curve

\begin{tabular}{cccc}
\hline ISIN & Maturity & Issuance & Coupon \\
\hline XS0268276473 & $15 / 09 / 2008$ & $15 / 09 / 2006$ & 3.600 \\
ES0200130435 & $18 / 12 / 2008$ & $26 / 03 / 1998$ & 5.000 \\
XS0088241772 & $18 / 12 / 2008$ & $24 / 06 / 1998$ & 5.000 \\
XS0169577714 & $22 / 12 / 2008$ & $05 / 06 / 2003$ & 3.000 \\
XS0236867247 & $16 / 03 / 2009$ & $05 / 12 / 2005$ & 2.875 \\
XS0297220641 & $15 / 09 / 2009$ & $25 / 04 / 2007$ & 4.125 \\
XS0285098710 & $01 / 02 / 2010$ & $01 / 02 / 2007$ & 4.000 \\
XS0366354875 & $27 / 05 / 2011$ & $27 / 05 / 2008$ & 4.375 \\
XS0436694607 & $30 / 06 / 2011$ & $30 / 06 / 2009$ & 2.121 \\
XS0441517660 & $27 / 07 / 2011$ & $27 / 07 / 2009$ & 1.920 \\
XS0403519068 & $09 / 12 / 2011$ & $09 / 12 / 2008$ & 3.375 \\
XS0417901641 & $16 / 03 / 2012$ & $17 / 03 / 2009$ & 2.875 \\
XS0502287203 & $15 / 04 / 2012$ & $15 / 04 / 2010$ & 1.480 \\
XS0301818166 & $23 / 05 / 2012$ & $23 / 05 / 2007$ & 4.375 \\
XS0437697740 & $02 / 07 / 2012$ & $02 / 07 / 2009$ & 2.500 \\
XS0633097299 & $16 / 05 / 2013$ & $02 / 06 / 2011$ & 3.875 \\
XS0525700778 & $15 / 07 / 2013$ & $15 / 07 / 2010$ & 3.750 \\
XS0386473267 & $10 / 09 / 2013$ & $10 / 09 / 2008$ & 4.500 \\
XS0452822520 & $18 / 09 / 2013$ & $18 / 09 / 2009$ & 2.500 \\
XS0408637022 & $20 / 01 / 2014$ & $20 / 01 / 2009$ & 3.500 \\
XS0485309313 & $10 / 02 / 2015$ & $10 / 02 / 2010$ & 3.250 \\
XS0485309313 & $10 / 02 / 2015$ & $10 / 02 / 2010$ & 3.250 \\
XS0513825280 & $30 / 04 / 2015$ & $02 / 06 / 2010$ & 2.900 \\
XS0528912214 & $28 / 07 / 2015$ & $28 / 07 / 2010$ & 3.750 \\
XS0455534692 & $16 / 09 / 2016$ & $02 / 10 / 2009$ & 1.200 \\
XS0428962921 & $20 / 05 / 2019$ & $20 / 05 / 2009$ & 4.375 \\
ES0200130369 & $28 / 12 / 2026$ & $24 / 07 / 1997$ & 6.750 \\
\hline & & &
\end{tabular}


Table A.2: KfW Bonds used for the estimation of the yield curve

\begin{tabular}{|c|c|c|c|}
\hline ISIN & Maturity & Issuance & Coupon \\
\hline DE0002760998 & $15 / 02 / 2008$ & $15 / 02 / 2006$ & 3.000 \\
\hline DE0002760907 & $25 / 04 / 2008$ & $20 / 02 / 2003$ & 3.250 \\
\hline DE0002760972 & $17 / 11 / 2008$ & 05/10/2005 & 2.500 \\
\hline DE0002760782 & 04/01/2009 & 01/04/1998 & 5.000 \\
\hline DE000A0E83R2 & $19 / 01 / 2009$ & $19 / 01 / 2007$ & 3.875 \\
\hline DE0002760923 & $17 / 04 / 2009$ & $12 / 02 / 2004$ & 3.500 \\
\hline DE000A0E83S0 & 30/06/2009 & 04/07/2007 & 4.375 \\
\hline DE0002760832 & 04/01/2010 & 08/09/1999 & 5.250 \\
\hline DE000A0E83C4 & $05 / 02 / 2010$ & 05/02/2008 & 3.750 \\
\hline DE000A0NKXX4 & 09/04/2010 & 27/03/2007 & 3.875 \\
\hline DE000A0E83D2 & $02 / 08 / 2010$ & 31/07/2008 & 4.875 \\
\hline DE0002760964 & $11 / 10 / 2010$ & $16 / 06 / 2005$ & 2.500 \\
\hline DE000A0E83E0 & $22 / 10 / 2010$ & $22 / 10 / 2008$ & 3.875 \\
\hline DE000A0XXM20 & $31 / 01 / 2011$ & 29/01/2009 & 2.250 \\
\hline DE000A0E9C91 & $08 / 04 / 2011$ & $22 / 04 / 2008$ & 4.000 \\
\hline DE0002760840 & 04/07/2011 & 29/03/2001 & 5.000 \\
\hline DE000A0KPWU7 & $14 / 10 / 2011$ & 20/09/2006 & 3.750 \\
\hline DE000A0Z1V18 & $05 / 12 / 2011$ & 05/06/2009 & 1.875 \\
\hline DE000A0XXM04 & $16 / 01 / 2012$ & $26 / 11 / 2008$ & 3.375 \\
\hline DE000A1DAMF4 & 23/03/2012 & 23/03/2010 & 1.125 \\
\hline DE000A0XXM87 & $21 / 05 / 2012$ & $20 / 05 / 2009$ & 2.250 \\
\hline DE0002760873 & 04/07/2012 & $13 / 03 / 2002$ & 5.250 \\
\hline DE000A0S8KS8 & $12 / 10 / 2012$ & $17 / 07 / 2007$ & 4.625 \\
\hline DE000A1DAMK4 & $17 / 06 / 2013$ & $15 / 06 / 2010$ & 1.250 \\
\hline DE0002760915 & 04/07/2013 & 03/07/2003 & 3.875 \\
\hline DE000A0E9DM0 & $11 / 10 / 2013$ & $17 / 09 / 2008$ & 4.375 \\
\hline DE000A1K0UE1 & $15 / 11 / 2013$ & $15 / 11 / 2011$ & 0.875 \\
\hline DE000A0XXM38 & $25 / 02 / 2014$ & $25 / 02 / 2009$ & 3.125 \\
\hline DE0002760931 & $04 / 07 / 2014$ & $29 / 04 / 2004$ & 4.250 \\
\hline DE000A1DAMJ6 & $10 / 04 / 2015$ & 28/04/2010 & 2.250 \\
\hline DE0002760956 & 04/07/2015 & $26 / 01 / 2005$ & 3.500 \\
\hline DE000A1EWEB2 & $16 / 11 / 2015$ & $16 / 11 / 2010$ & 1.875 \\
\hline DE000A1H36V3 & $08 / 04 / 2016$ & $19 / 04 / 2011$ & 3.125 \\
\hline DE000A0Z2KS2 & 04/07/2016 & 02/12/2009 & 3.125 \\
\hline DE000A1K0UB7 & 07/09/2016 & 07/09/2011 & 2.000 \\
\hline DE000A1DAME7 & $22 / 03 / 2017$ & $22 / 03 / 2010$ & 2.875 \\
\hline DE000A0MFJX5 & 04/07/2017 & $30 / 01 / 2007$ & 4.125 \\
\hline DE000A1H36X9 & $15 / 06 / 2018$ & $15 / 06 / 2011$ & 3.125 \\
\hline DE000A0SLD89 & $04 / 07 / 2018$ & $16 / 01 / 2008$ & 4.375 \\
\hline DE000A0L1CY5 & $21 / 01 / 2019$ & $20 / 01 / 2009$ & 3.875 \\
\hline DE000A1CR4S5 & $20 / 01 / 2020$ & $19 / 01 / 2010$ & 3.625 \\
\hline DE000A1EWEJ5 & $18 / 01 / 2021$ & $18 / 01 / 2011$ & 3.375 \\
\hline DE0002760980 & $04 / 07 / 2021$ & $17 / 01 / 2006$ & 3.500 \\
\hline DE000A0PM5F0 & 04/01/2023 & $16 / 10 / 2007$ & 4.625 \\
\hline
\end{tabular}


Table A.3: CADES Bonds used for the estimation of the yield curve

\begin{tabular}{llcc}
\hline ISIN & Maturity & Issuance & Coupon \\
\hline FR0000571259 & $25 / 10 / 2008$ & $02 / 02 / 1998$ & 5.125 \\
FR0010295949 & $23 / 02 / 2009$ & $23 / 02 / 2006$ & 3.125 \\
FR0010093377 & $12 / 07 / 2009$ & $23 / 06 / 2004$ & 3.750 \\
FR0010173773 & $12 / 07 / 2010$ & $22 / 03 / 2005$ & 3.125 \\
FR0010718338 & $25 / 04 / 2012$ & $29 / 01 / 2009$ & 2.625 \\
FR0000571366 & $25 / 10 / 2012$ & $27 / 03 / 1998$ & 5.250 \\
FR0010249763 & $25 / 04 / 2013$ & $04 / 11 / 2005$ & 3.250 \\
FR0010660100 & $04 / 09 / 2013$ & $04 / 09 / 2008$ & 4.500 \\
FR0011147701 & $18 / 11 / 2013$ & $18 / 11 / 2011$ & 1.750 \\
FR0010120410 & $25 / 10 / 2014$ & $11 / 10 / 2004$ & 4.000 \\
FR0010831669 & $15 / 01 / 2015$ & $08 / 12 / 2009$ & 2.625 \\
FR0011185032 & $16 / 02 / 2015$ & $24 / 01 / 2012$ & 1.875 \\
FR0010163329 & $25 / 04 / 2015$ & $09 / 02 / 2005$ & 3.625 \\
FR0011008366 & $25 / 02 / 2016$ & $16 / 02 / 2011$ & 3.000 \\
FR0010301747 & $25 / 04 / 2016$ & $08 / 03 / 2006$ & 3.625 \\
FR0010456434 & $25 / 04 / 2017$ & $12 / 04 / 2007$ & 4.125 \\
FR0010143743 & $25 / 10 / 2019$ & $21 / 12 / 2004$ & 4.000 \\
FR0010767566 & $25 / 04 / 2020$ & $10 / 06 / 2009$ & 4.250 \\
FR0010198036 & $25 / 10 / 2020$ & $27 / 05 / 2005$ & 3.750 \\
FR0010915660 & $25 / 04 / 2021$ & $29 / 06 / 2010$ & 3.375 \\
FR0010347989 & $25 / 10 / 2021$ & $25 / 07 / 2006$ & 4.375 \\
FR0011037001 & $25 / 04 / 2023$ & $18 / 04 / 2011$ & 4.125 \\
FR0011192392 & $15 / 12 / 2025$ & $01 / 02 / 2012$ & 4.000 \\
\hline
\end{tabular}


Table A.4: Spanish Government Bonds used for the estimation of the yield curve

\begin{tabular}{lccc}
\hline \multicolumn{1}{c}{ ISIN } & Maturity & Issuance & Coupon \\
\hline ES0000011652 & $31 / 01 / 2008$ & $15 / 07 / 1997$ & 6.000 \\
ES00000120H2 & $31 / 10 / 2008$ & $17 / 01 / 2006$ & 2.900 \\
ES0000012882 & $31 / 01 / 2009$ & $19 / 01 / 2004$ & 3.600 \\
ES0000012064 & $30 / 07 / 2009$ & $10 / 07 / 1998$ & 5.150 \\
ES0000012239 & $31 / 01 / 2010$ & $11 / 05 / 1999$ & 4.000 \\
ES00000120E9 & $30 / 07 / 2010$ & $12 / 04 / 2005$ & 3.250 \\
ES00000120Z4 & $30 / 04 / 2011$ & $15 / 01 / 2008$ & 4.100 \\
ES0000012387 & $30 / 07 / 2011$ & $19 / 09 / 2000$ & 5.400 \\
ES0000012452 & $31 / 10 / 2011$ & $12 / 06 / 2001$ & 5.350 \\
ES00000121I8 & $30 / 04 / 2012$ & $13 / 01 / 2009$ & 2.750 \\
ES0000012791 & $30 / 07 / 2012$ & $14 / 05 / 2002$ & 5.000 \\
ES00000120L4 & $31 / 10 / 2012$ & $16 / 01 / 2007$ & 3.900 \\
ES0000011660 & $31 / 01 / 2013$ & $15 / 07 / 1997$ & 6.150 \\
EH988544 & $30 / 04 / 2013$ & $06 / 10 / 2009$ & 2.300 \\
ES0000012866 & $30 / 07 / 2013$ & $15 / 04 / 2003$ & 4.200 \\
EI263529 & $31 / 10 / 2013$ & $15 / 06 / 2010$ & 2.500 \\
ES00000121H0 & $31 / 01 / 2014$ & $07 / 10 / 2008$ & 4.250 \\
ES00000123D5 & $30 / 04 / 2014$ & $12 / 04 / 2011$ & 3.400 \\
ES0000012098 & $30 / 07 / 2014$ & $07 / 12 / 1998$ & 4.750 \\
EH885945 & $31 / 10 / 2014$ & $07 / 07 / 2009$ & 3.300 \\
ES0000012916 & $31 / 01 / 2015$ & $28 / 06 / 2004$ & 4.400 \\
EI169668 & $30 / 04 / 2015$ & $09 / 03 / 2010$ & 3.000 \\
ES00000123L8 & $30 / 07 / 2015$ & $17 / 01 / 2012$ & 4.000 \\
ES00000120G4 & $31 / 01 / 2016$ & $20 / 09 / 2005$ & 3.150 \\
ES00000122X5 & $30 / 04 / 2016$ & $09 / 11 / 2010$ & 3.250 \\
ES00000123J2 & $31 / 10 / 2016$ & $06 / 09 / 2011$ & 4.250 \\
ES00000120J8 & $31 / 01 / 2017$ & $18 / 10 / 2006$ & 3.800 \\
ES0000012783 & $30 / 07 / 2017$ & $11 / 03 / 2002$ & 5.500 \\
ES00000121A5 & $30 / 07 / 2018$ & $19 / 02 / 2008$ & 4.100 \\
ES00000121L2 & $30 / 07 / 2019$ & $10 / 02 / 2009$ & 4.600 \\
ES00000121O6 & $31 / 10 / 2019$ & $02 / 06 / 2009$ & 4.300 \\
EI109866 & $30 / 04 / 2020$ & $20 / 01 / 2010$ & 4.000 \\
ES00000122T3 & $31 / 10 / 2020$ & $13 / 07 / 2010$ & 4.850 \\
ES00000123B9 & $30 / 04 / 2021$ & $24 / 01 / 2011$ & 5.500 \\
ES00000123K0 & $31 / 01 / 2022$ & $22 / 11 / 2011$ & 5.850 \\
ES00000121G2 & $31 / 01 / 2024$ & $16 / 09 / 2008$ & 4.800 \\
EI153632 & $30 / 07 / 2025$ & $24 / 02 / 2010$ & 4.650 \\
ES00000123C7 & $30 / 07 / 2026$ & $15 / 03 / 2011$ & 5.900 \\
ES0000011868 & $31 / 01 / 2029$ & $15 / 01 / 1998$ & 6.000 \\
ES0000012411 & $30 / 07 / 2032$ & $23 / 01 / 2001$ & 5.750 \\
ES0000012932 & $31 / 01 / 2037$ & $17 / 01 / 2005$ & 4.200 \\
ES00000120N0 & $03 / 07 / 2040$ & $20 / 06 / 2007$ & 4.900 \\
EH984269 & $30 / 07 / 2041$ & $28 / 09 / 2009$ & 4.700 \\
\hline & & & \\
& & &
\end{tabular}


Table A.5: German Government Bonds used for the estimation of the yield curve

\begin{tabular}{|c|c|c|c|}
\hline ISIN & Maturity & Issuance & Coupon \\
\hline DE0001137131 & $14 / 03 / 2008$ & $10 / 03 / 2006$ & 3.000 \\
\hline DE0001141422 & 11/04/2008 & $16 / 05 / 2003$ & 3.000 \\
\hline DE0001137149 & 13/06/2008 & 23/06/2006 & 3.250 \\
\hline DE0001135077 & 04/07/2008 & 10/07/1998 & 4.750 \\
\hline DE0001135093 & 04/07/2008 & 30/10/1998 & 4.125 \\
\hline DE0001137156 & 12/09/2008 & 15/09/2006 & 3.500 \\
\hline DE0001141430 & 10/10/2008 & 10/10/2003 & 3.500 \\
\hline DE0001137164 & 12/12/2008 & 15/12/2006 & 3.750 \\
\hline DE0001135101 & 04/01/2009 & 08/01/1999 & 3.750 \\
\hline DE0001137172 & 13/03/2009 & 16/03/2007 & 3.750 \\
\hline DE0001141448 & 17/04/2009 & $13 / 02 / 2004$ & 3.250 \\
\hline DE0001137180 & 12/06/2009 & 15/06/2007 & 4.500 \\
\hline DE0001137198 & 11/09/2009 & $14 / 09 / 2007$ & 4.000 \\
\hline DE0001141455 & 09/10/2009 & $27 / 08 / 2004$ & 3.500 \\
\hline DE0001137206 & 11/12/2009 & $14 / 12 / 2007$ & 4.000 \\
\hline DE0001135135 & 04/01/2010 & 22/10/1999 & 5.375 \\
\hline DE0001137214 & $12 / 03 / 2010$ & $14 / 03 / 2008$ & 3.000 \\
\hline DE0001141463 & 09/04/2010 & $01 / 04 / 2005$ & 3.250 \\
\hline DE0001137222 & 11/06/2010 & $13 / 06 / 2008$ & 4.750 \\
\hline DE0001135150 & 04/07/2010 & 05/05/2000 & 5.250 \\
\hline DE0001137230 & 10/09/2010 & $12 / 09 / 2008$ & 4.000 \\
\hline DE0001141471 & 08/10/2010 & 23/09/2005 & 2.500 \\
\hline DE0001137248 & 10/12/2010 & $12 / 12 / 2008$ & 2.250 \\
\hline DE0001135168 & 04/01/2011 & 20/10/2000 & 5.250 \\
\hline DE0001137255 & 11/03/2011 & 13/03/2009 & 1.250 \\
\hline DE0001141489 & 08/04/2011 & $24 / 03 / 2006$ & 3.500 \\
\hline DE0001137263 & 10/06/2011 & 29/05/2009 & 1.500 \\
\hline DE0001135184 & 04/07/2011 & $25 / 05 / 2001$ & 5.000 \\
\hline DE0001137271 & 16/09/2011 & 11/09/2009 & 1.250 \\
\hline DE0001141497 & $14 / 10 / 2011$ & $29 / 09 / 2006$ & 3.500 \\
\hline DE0001137289 & $16 / 12 / 2011$ & 20/11/2009 & 1.250 \\
\hline DE0001135192 & 04/01/2012 & 04/01/2002 & 5.000 \\
\hline DE0001137297 & 16/03/2012 & $19 / 02 / 2010$ & 1.000 \\
\hline DE0001141505 & $13 / 04 / 2012$ & $30 / 03 / 2007$ & 4.000 \\
\hline DE0001137305 & 15/06/2012 & $14 / 05 / 2010$ & 0.500 \\
\hline DE0001135200 & 04/07/2012 & 05/07/2002 & 5.000 \\
\hline DE0001137313 & 14/09/2012 & 13/08/2010 & 0.750 \\
\hline DE0001141513 & $12 / 10 / 2012$ & 28/09/2007 & 4.250 \\
\hline DE0001137321 & $14 / 12 / 2012$ & $12 / 11 / 2010$ & 1.000 \\
\hline DE0001135218 & 04/01/2013 & $10 / 01 / 2003$ & 4.500 \\
\hline DE0001137339 & 15/03/2013 & $25 / 02 / 2011$ & 1.500 \\
\hline DE0001141521 & $12 / 04 / 2013$ & $28 / 03 / 2008$ & 3.500 \\
\hline DE0001137347 & $14 / 06 / 2013$ & $13 / 05 / 2011$ & 1.750 \\
\hline DE0001137354 & 13/09/2013 & 19/08/2011 & 0.750 \\
\hline DE0001141539 & $11 / 10 / 2013$ & $26 / 09 / 2008$ & 4.000 \\
\hline DE0001137362 & $13 / 12 / 2013$ & $18 / 11 / 2011$ & 0.250 \\
\hline DE0001135242 & 04/01/2014 & $31 / 10 / 2003$ & 4.250 \\
\hline DE0001137370 & $14 / 03 / 2014$ & 24/02/2012 & 0.250 \\
\hline DE0001141547 & $11 / 04 / 2014$ & 27/03/2009 & 2.250 \\
\hline DE0001135259 & 04/07/2014 & $28 / 05 / 2004$ & 4.250 \\
\hline DE0001141554 & $10 / 10 / 2014$ & $25 / 09 / 2009$ & 2.500 \\
\hline DE0001135267 & 04/01/2015 & $26 / 11 / 2004$ & 3.750 \\
\hline DE0001141562 & 27/02/2015 & $15 / 01 / 2010$ & 2.500 \\
\hline DE0001141570 & 10/04/2015 & $16 / 04 / 2010$ & 2.250 \\
\hline DE0001135283 & 04/07/2015 & $20 / 05 / 2005$ & 3.250 \\
\hline DE0001141588 & 09/10/2015 & 24/09/2010 & 1.750 \\
\hline DE0001135291 & 04/01/2016 & $25 / 11 / 2005$ & 3.500 \\
\hline DE0001141596 & 26/02/2016 & $14 / 01 / 2011$ & 2.000 \\
\hline DE0001141604 & 08/04/2016 & $26 / 04 / 2011$ & 2.750 \\
\hline DE0001135309 & 04/07/2016 & $19 / 05 / 2006$ & 4.000 \\
\hline DE0001141612 & $14 / 10 / 2016$ & 30/09/2011 & 1.250 \\
\hline DE0001135317 & 04/01/2017 & $17 / 11 / 2006$ & 3.750 \\
\hline DE0001141620 & $24 / 02 / 2017$ & 13/01/2012 & 0.750 \\
\hline DE0001135333 & $04 / 07 / 2017$ & $25 / 05 / 2007$ & 4.250 \\
\hline
\end{tabular}




\begin{tabular}{cccc}
\hline ISIN & Maturity & Issuance & Coupon \\
\hline DE0001135341 & $04 / 01 / 2018$ & $16 / 11 / 2007$ & 4.000 \\
DE0001135358 & $04 / 07 / 2018$ & $30 / 05 / 2008$ & 4.250 \\
DE0001135374 & $04 / 01 / 2019$ & $14 / 11 / 2008$ & 3.750 \\
DE0001135382 & $04 / 07 / 2019$ & $22 / 05 / 2009$ & 3.500 \\
DE0001135390 & $04 / 01 / 2020$ & $13 / 11 / 2009$ & 3.250 \\
DE0001135408 & $04 / 07 / 2020$ & $30 / 04 / 2010$ & 3.000 \\
DE0001135416 & $04 / 09 / 2020$ & $20 / 08 / 2010$ & 2.250 \\
DE0001135424 & $04 / 01 / 2021$ & $26 / 11 / 2010$ & 2.500 \\
DE0001135440 & $04 / 07 / 2021$ & $29 / 04 / 2011$ & 3.250 \\
DE0001135457 & $04 / 09 / 2021$ & $26 / 08 / 2011$ & 2.250 \\
DE0001135465 & $04 / 01 / 2022$ & $25 / 11 / 2011$ & 2.000 \\
DE0001135473 & $04 / 07 / 2022$ & $13 / 04 / 2012$ & 1.75 \\
DE0001134922 & $04 / 01 / 2024$ & $04 / 01 / 1994$ & 6.250 \\
DE0001135044 & $04 / 07 / 2027$ & $04 / 07 / 1997$ & 6.500 \\
DE0001135069 & $04 / 01 / 2028$ & $23 / 01 / 1998$ & 5.625 \\
DE0001135143 & $04 / 01 / 2030$ & $21 / 01 / 2000$ & 6.250 \\
DE0001135176 & $04 / 01 / 2031$ & $27 / 10 / 2000$ & 5.500 \\
DE0001135226 & $04 / 07 / 2034$ & $31 / 01 / 2003$ & 4.750 \\
DE0001135275 & $04 / 01 / 2037$ & $28 / 01 / 2005$ & 4.000 \\
DE0001135325 & $04 / 07 / 2039$ & $26 / 01 / 2007$ & 4.250 \\
DE0001135366 & $04 / 07 / 2040$ & $25 / 07 / 2008$ & 4.750 \\
DE0001135432 & $04 / 07 / 2042$ & $23 / 07 / 2010$ & 3.25 \\
\hline
\end{tabular}


Table A.6: French Government Bonds used for the estimation of the yield curve

\begin{tabular}{|c|c|c|c|}
\hline ISIN & Maturity & Issuance & Coupon \\
\hline FR0105427795 & $12 / 01 / 2008$ & $28 / 01 / 2003$ & 3.500 \\
\hline FR0108197569 & $12 / 03 / 2008$ & $22 / 11 / 2005$ & 2.750 \\
\hline FR0000570632 & $25 / 04 / 2008$ & 15/01/1998 & 5.250 \\
\hline FR0105760112 & $12 / 07 / 2008$ & $24 / 06 / 2003$ & 3.000 \\
\hline FR0109136137 & $12 / 09 / 2008$ & 25/07/2006 & 3.500 \\
\hline FR0000570665 & 25/10/2008 & 25/06/1992 & 8.500 \\
\hline FR0106589437 & $12 / 01 / 2009$ & $22 / 01 / 2004$ & 3.500 \\
\hline FR0000571432 & 25/04/2009 & 08/10/1998 & 4.000 \\
\hline FR0106841887 & 12/07/2009 & $22 / 06 / 2004$ & 3.500 \\
\hline FR0110979178 & 12/09/2009 & $24 / 04 / 2007$ & 4.000 \\
\hline FR0000186199 & 25/10/2009 & 12/05/1999 & 4.000 \\
\hline FR0107369672 & $12 / 01 / 2010$ & $23 / 11 / 2004$ & 3.000 \\
\hline FR0000186603 & $25 / 04 / 2010$ & 08/02/2000 & 5.500 \\
\hline FR0107674006 & $12 / 07 / 2010$ & 21/06/2005 & 2.500 \\
\hline FR0113872776 & $12 / 09 / 2010$ & 20/05/2008 & 3.750 \\
\hline FR0000187023 & $25 / 10 / 2010$ & $12 / 09 / 2000$ & 5.500 \\
\hline FR0108354806 & $12 / 01 / 2011$ & 24/01/2006 & 3.000 \\
\hline FR0000570731 & $25 / 04 / 2011$ & 26/02/1996 & 6.500 \\
\hline FR0108847049 & 12/07/2011 & 20/06/2006 & 3.500 \\
\hline FR0116843519 & $12 / 09 / 2011$ & 26/05/2009 & 1.500 \\
\hline FR0000187874 & $25 / 10 / 2011$ & 11/09/2001 & 5.000 \\
\hline FR0109970386 & $12 / 01 / 2012$ & 23/01/2007 & 3.750 \\
\hline FR0000188328 & 25/04/2012 & $12 / 03 / 2002$ & 5.000 \\
\hline FR0110979186 & 12/07/2012 & $26 / 06 / 2007$ & 4.500 \\
\hline FR0000188690 & 25/10/2012 & 10/09/2002 & 4.750 \\
\hline FR0000570780 & 26/12/2012 & 25/02/1987 & 8.500 \\
\hline FR0113087466 & $12 / 01 / 2013$ & $22 / 01 / 2008$ & 3.750 \\
\hline FR0000188989 & $25 / 04 / 2013$ & 11/03/2003 & 4.000 \\
\hline FR0114683842 & $12 / 07 / 2013$ & $22 / 07 / 2008$ & 4.500 \\
\hline FR0010011130 & 25/10/2013 & 09/09/2003 & 4.000 \\
\hline FR0010061242 & $25 / 04 / 2014$ & 09/03/2004 & 4.000 \\
\hline FR0010112052 & $25 / 10 / 2014$ & 07/09/2004 & 4.000 \\
\hline FR0117836652 & $15 / 01 / 2015$ & $26 / 01 / 2010$ & 2.500 \\
\hline FR0010163543 & $25 / 04 / 2015$ & 08/02/2005 & 3.500 \\
\hline FR0118462128 & $12 / 07 / 2015$ & $22 / 06 / 2010$ & 2.000 \\
\hline FR0010216481 & 25/10/2015 & $12 / 07 / 2005$ & 3.000 \\
\hline FR0119105809 & $25 / 02 / 2016$ & $25 / 01 / 2011$ & 2.250 \\
\hline FR0010288357 & 25/04/2016 & 07/02/2006 & 3.250 \\
\hline FR0119580050 & 25/07/2016 & 21/06/2011 & 2.500 \\
\hline FR0000187361 & $25 / 10 / 2016$ & 06/02/2001 & 5.000 \\
\hline FR0120473253 & 25/02/2017 & 21/02/2012 & 1.750 \\
\hline FR0010415331 & $25 / 04 / 2017$ & 09/01/2007 & 3.750 \\
\hline FR0010517417 & 25/10/2017 & 11/09/2007 & 4.250 \\
\hline FR0010604983 & $25 / 04 / 2018$ & 08/04/2008 & 4.000 \\
\hline FR0010670737 & $25 / 10 / 2018$ & 07/10/2008 & 4.250 \\
\hline FR0000189151 & 25/04/2019 & 10/06/2003 & 4.250 \\
\hline FR0000570921 & 25/10/2019 & 25/01/1989 & 8.500 \\
\hline FR0010776161 & 25/10/2019 & 07/07/2009 & 3.750 \\
\hline FR0010854182 & $25 / 04 / 2020$ & 09/02/2010 & 3.500 \\
\hline FR0010949651 & $25 / 10 / 2020$ & $12 / 10 / 2010$ & 2.500 \\
\hline FR0010192997 & $25 / 04 / 2021$ & $10 / 05 / 2005$ & 3.750 \\
\hline FR0011059088 & 25/10/2021 & 07/06/2011 & 3.250 \\
\hline FR0011196856 & $25 / 04 / 2022$ & 07/02/2012 & 3.000 \\
\hline FR0000571085 & 25/04/2023 & 27/01/1992 & 8.500 \\
\hline FR0010466938 & $25 / 10 / 2023$ & 09/05/2007 & 4.250 \\
\hline FR0000571150 & $25 / 10 / 2025$ & 25/02/1994 & 6.000 \\
\hline FR0010916924 & $25 / 04 / 2026$ & 06/07/2010 & 3.500 \\
\hline FR0000571218 & 25/04/2029 & 12/03/1998 & 5.500 \\
\hline FR0000187635 & 25/10/2032 & $12 / 06 / 2001$ & 5.750 \\
\hline FR0010070060 & 25/04/2035 & 06/04/2004 & 4.750 \\
\hline FR0010371401 & 25/10/2038 & 12/09/2006 & 4.000 \\
\hline FR0010773192 & 25/04/2041 & 30/06/2009 & 4.500 \\
\hline FR0010171975 & $25 / 04 / 2055$ & $28 / 02 / 2005$ & 4.000 \\
\hline
\end{tabular}




\section{BANCO DE ESPAÑA PUBLICATIONS}

\section{WORKING PAPERS}

1301 JAMES COSTAIN and ANTON NAKOV: Logit price dynamics.

1302 MIGUEL GARCÍA-POSADA: Insolvency institutions and efficiency: the Spanish case.

1303 MIGUEL GARCÍA-POSADA and JUAN S. MORA-SANGUINETTI: Firm size and judicial efficacy: evidence for the new civil procedures in Spain.

1304 MAXIMO CAMACHO and GABRIEL PEREZ-QUIROS: Commodity prices and the business cycle in Latin America: living and dying by commodities?

1305 CARLOS PÉREZ MONTES: Estimation of regulatory credit risk models.

1306 FERNANDO LÓPEZ VICENTE: The effect of foreclosure regulation: evidence for the US mortgage market at state level.

1307 ENRIQUE MORAL-BENITO and LUIS SERVEN: Testing weak exogeneity in cointegrated panels.

1308 EMMA BERENGUER, RICARDO GIMENO and JUAN M. NAVE: Term structure estimation, liquidity-induced heteroskedasticity and the price of liquidity risk.

1309 PABLO HERNÁNDEZ DE COS and ENRIQUE MORAL-BENITO: Fiscal multipliers in turbulent times: the case of Spain.

1310 SAMUEL HURTADO: DSGE models and the Lucas critique.

1311 HENRIQUE S. BASSO and JAMES COSTAIN: Fiscal delegation in a monetary union with decentralized public spending

1312 MAITE BLÁZQUEZ CUESTA and SANTIAGO BUDRÍA: Does income deprivation affect people's mental well-being?

1313 ENRIQUE ALBEROLA, ÁNGEL ESTRADA and DANIEL SANTABÁRBARA: Growth beyond imbalances. Sustainable growth rates and output gap reassessment.

1314 CARMEN BROTO and GABRIEL PEREZ-QUIROS: Disentangling contagion among sovereign CDS spreads during the European debt crisis.

1315 MIGUEL GARCÍA-POSADA and JUAN S. MORA-SANGUINETTI: Are there alternatives to bankruptcy? A study of small business distress in Spain.

1316 ROBERTO RAMOS and ENRIQUE MORAL-BENITO: Agglomeration matters for trade.

1317 LAURA HOSPIDO and GEMA ZAMARRO: Retirement patterns of couples in Europe.

1318 MAXIMO CAMACHO, GABRIEL PEREZ-QUIROS and PILAR PONCELA: Short-term forecasting for empirical economists. A survey of the recently proposed algorithms.

1319 CARLOS PÉREZ MONTES: The impact of interbank and public debt markets on the competition for bank deposits.

1320 OLYMPIA BOVER, JOSE MARIA CASADO, SONIA COSTA, PHILIP DU CAJU, YVONNE MCCARTHY, EVA SIERMINSKA, PANAGIOTA TZAMOURANI, ERNESTO VILLANUEVA and TIBOR ZAVADIL: The distribution of debt across euro area countries: the role of Individual characteristics, institutions and credit conditions.

1321 BRINDUSA ANGHEL, SARA DE LA RICA and AITOR LACUESTA: Employment polarisation in Spain over the course of the 1997-2012 cycle.

1322 RODOLFO G. CAMPOS and ILIANA REGGIO: Measurement error in imputation procedures.

1323 PABLO BURRIEL and MARÍA ISABEL GARCÍA-BELMONTE: Meeting our D€STINY. A Disaggregated €uro area Short Term Indicator model to forecast GDP $(Y)$ growth.

1401 TERESA SASTRE and FRANCESCA VIANI: Countries' safety and competitiveness, and the estimation of current account misalignments.

1402 FERNANDO BRONER, ALBERTO MARTIN, AITOR ERCE and JAUME VENTURA: Sovereign debt markets in turbulent times: creditor discrimination and crowding-out effects.

1403 JAVIER J. PÉREZ and ROCÍO PRIETO: The structure of sub-national public debt: liquidity vs credit risks.

1404 BING XU, ADRIAN VAN RIXTEL and MICHIEL VAN LEUVENSTEIJN: Measuring bank competition in China: a comparison of new versus conventional approaches applied to loan markets.

1405 MIGUEL GARCÍA-POSADA and JUAN S. MORA-SANGUINETTI: Entrepreneurship and enforcement institutions: disaggregated evidence for Spain.

1406 MARIYA HAKE, FERNANDO LÓPEZ-VICENTE and LUIS MOLINA: Do the drivers of loan dollarisation differ between CESEE and Latin America? A meta-analysis.

1407 JOSÉ MANUEL MONTERO and ALBERTO URTASUN: Price-cost mark-ups in the Spanish economy: a microeconomic perspective.

1408 FRANCISCO DE CASTRO, FRANCISCO MARTÍ, ANTONIO MONTESINOS, JAVIER J. PÉREZ and A. JESÚS SÁNCHEZ-FUENTES: Fiscal policies in Spain: main stylised facts revisited. 
1409 MARÍA J. NIETO: Third-country relations in the Directive establishing a framework for the recovery and resolution of credit institutions.

1410 ÓSCAR ARCE and SERGIO MAYORDOMO: Short-sale constraints and financial stability: evidence from the Spanish market.

1411 RODOLFO G. CAMPOS and ILIANA REGGIO: Consumption in the shadow of unemployment.

1412 PAUL EHLING and DAVID HAUSHALTER: When does cash matter? Evidence for private firms.

1413 PAUL EHLING and CHRISTIAN HEYERDAHL-LARSEN: Correlations.

1414 IRINA BALTEANU and AITOR ERCE: Banking crises and sovereign defaults in emerging markets: exploring the links.

1415 ÁNGEL ESTRADA, DANIEL GARROTE, EVA VALDEOLIVAS and JAVIER VALLÉS: Household debt and uncertainty: private consumption after the Great Recession.

1416 DIEGO J. PEDREGAL, JAVIER J. PÉREZ and A. JESÚS SÁNCHEZ-FUENTES: A toolkit to strengthen government budget surveillance.

1417 J. IGNACIO CONDE-RUIZ, and CLARA I. GONZÁLEZ: From Bismarck to Beveridge: the other pension reform in Spain.

1418 PABLO HERNÁNDEZ DE COS, GERRIT B. KOESTER, ENRIQUE MORAL-BENITO and CHRISTIANE NICKEL: Signalling fiscal stress in the euro area: a country-specific early warning system.

1419 MIGUEL ALMUNIA and DAVID LÓPEZ-RODRÍGUEZ: Heterogeneous responses to effective tax enforcement: evidence from Spanish firms.

1420 ALFONSO R. SÁNCHEZ: The automatic adjustment of pension expenditures in Spain: an evaluation of the 2013 pension reform.

1421 JAVIER ANDRÉS, ÓSCAR ARCE and CARLOS THOMAS: Structural reforms in a debt overhang.

1422 LAURA HOSPIDO and ENRIQUE MORAL-BENITO: The public sector wage premium in Spain: evidence from longitudinal administrative data.

1423 MARÍA DOLORES GADEA-RIVAS, ANA GÓMEZ-LOSCOS and GABRIEL PÉREZ-QUIRÓS: The Two Greatest. Great Recession vs. Great Moderation.

1424 ENRIQUE MORAL-BENITO and OLIVER ROEHN: The impact of financial (de)regulation on current account balances

1425 MÁXIMO CAMACHO and JAIME MARTÍNEZ-MARTÍN: Real-time forecasting US GDP from small-scale factor models.

1426 ALFREDO MARTÍN OLIVER, SONIA RUANO PARDO and VICENTE SALAS FUMÁS: Productivity and welfare: an application to the Spanish banking industry.

1427 JAVIER ANDRÉS and PABLO BURRIEL: Inflation dynamics in a model with firms' entry and (some) heterogeneity.

1428 CARMEN BROTO and LUIS MOLINA: Sovereign ratings and their asymmetric response to fundamentals.

1429 JUAN ÁNGEL GARCÍA and RICARDO GIMENO: Flight-to-liquidity flows in the euro area sovereign debt crisis.

\section{BANCODEESPAÑA}

\section{Eurosistema}

Unidad de Servicios Auxiliares

Alcalá, 48 - 28014 Madrid

E-mail: publicaciones@bde.es www.bde.es 